QA: N/A

MOL . 20010725.0119

\title{
Documentation of National Weather Conditions Affecting Long-Term Degradation of Commercial Spent Nuclear Fuel and DOE Spent Nuclear Fuel and High-Level Waste
}

\author{
Prepared for \\ Jason Technologies \\ 6655 West Sahara Avenue \\ Las Vegas, NV 89102 \\ Report Prepared for Use in Preparation \\ of the Yucca Mountain \\ Environmental Impact Statement \\ Report by \\ W. Lee Poe, Jr. and Paul F. Wise \\ Tetra Tech NUS, Inc. \\ 900 Trail Ridge Road \\ Aiken, SC 29803
}

November 1998 


\section{TABLE OF CONTENTS}

$\underline{\text { Section }}$

1.0 Introduction 1

2.0 Concrete Storage Module Degradation ........................................................................................ 1

2.1 Concrete Degradation from Freeze/Thaw ................................................................................ 3

2.2 Concrete Degradation Aboveground Storage Facilities from Chemical Attack

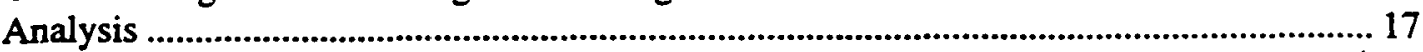

2.2.1 Concrete Degradation for Underground Concrete Vaults (from Section 4.2.2 of Reference 2) .

2.2.2 Concrete Degradation for Surface Concrete Facilities ......................................... 18

2.2.2.1 Sulfate and Magnesium Attack .............................................................. 18

2.2.2.2 Calcium Hydroxide Leaching............................................................ 19

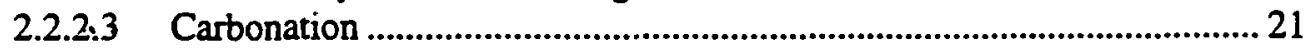

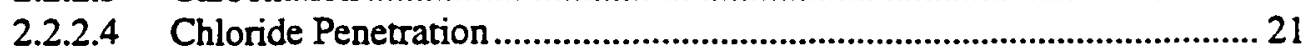

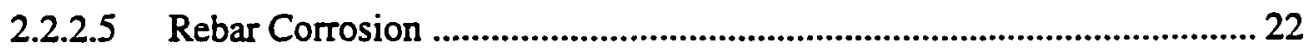

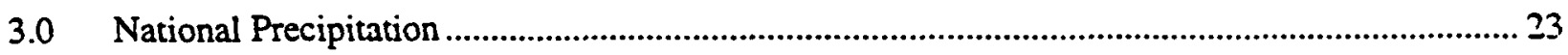

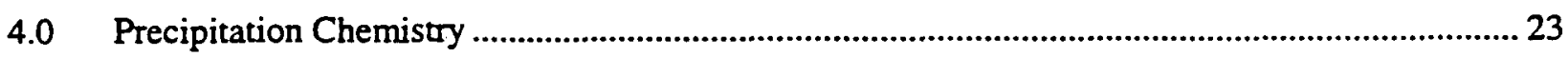

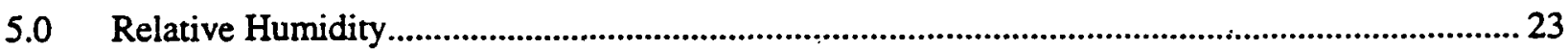

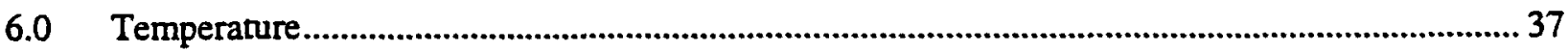

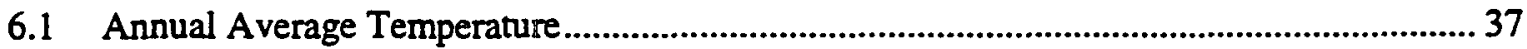

6:2 Thermal Analysis of Surface Storage of Commercial SNF ................................................ 37

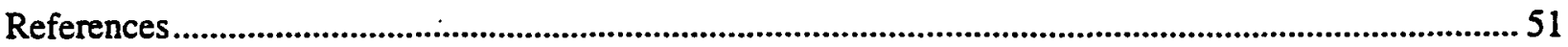

\section{List of Tables}

Table $\quad \underline{\text { Page }}$

2-1 Example information for concrete freeze/thaw (times are from loss of institutional control)........ 2

2-2 Commercial reactor freeze /thaw data ............................................................................................

2-3 Precipitation chemistry for Barnwell, South Carolina................................................................... 17

2-4 Concrete damage in underground concrete facilities.............................................................. 18

2-5 Concrete degradation (inches) - no freeze/thaw degradation ..................................................20

3-1 Nuclear sites in various precipitation regions.........................................................................25

3-2 Annual precipitation (inches/yr) at sites with less than 30 inches of precipitation ...................... 25

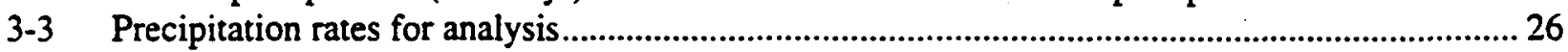

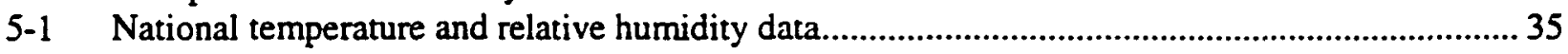




\section{TABLE OF CONTENTS (Continued)}

\section{List of Figures}

Figure

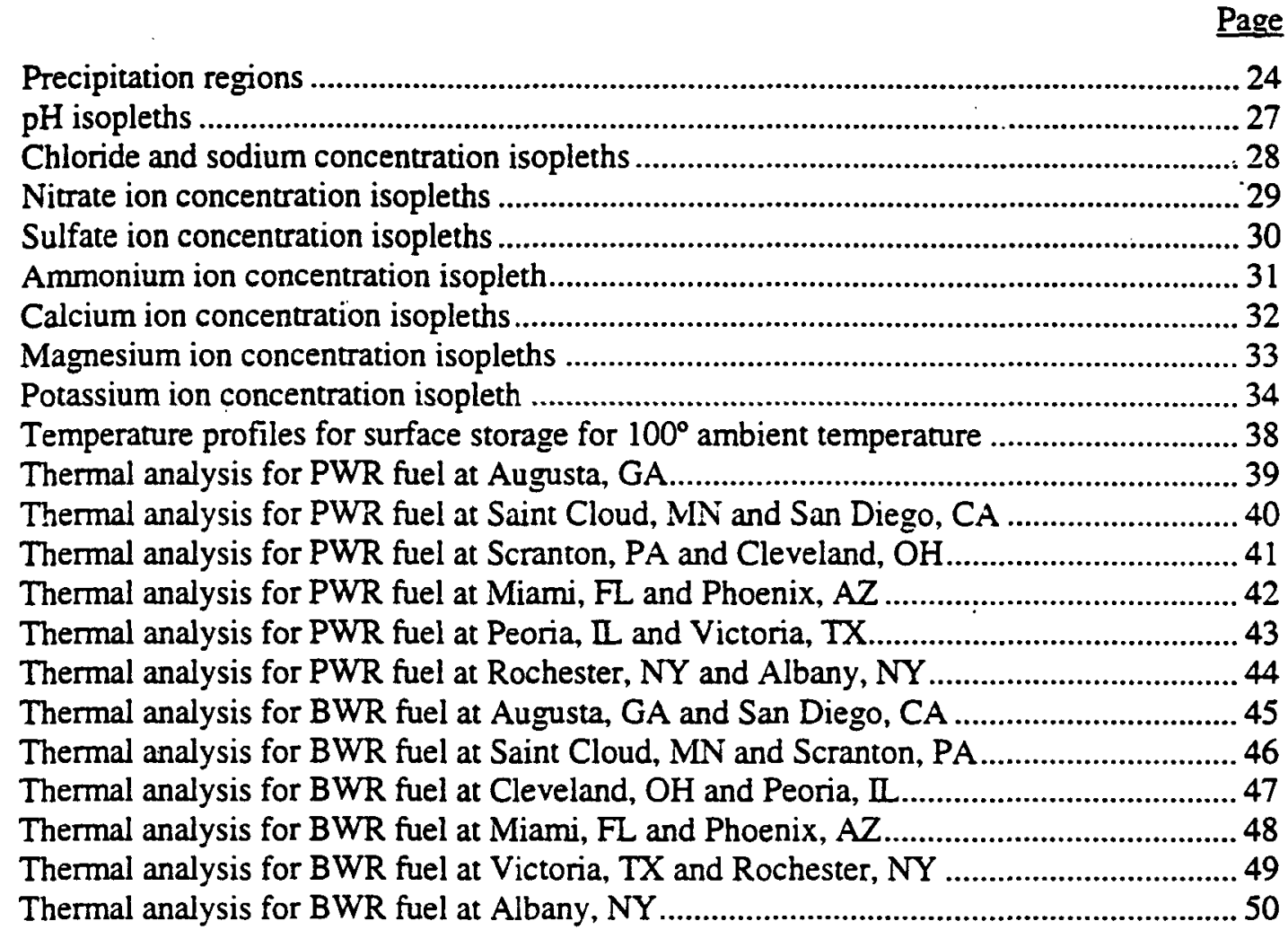




\section{Documentation of National Weather Conditions Affecting Long-Term Degradation of Commercial Spent Nuclear Fuel and DOE Sperit Nuclear Fuel and High-Level Waste}

\subsection{Introduction}

The U.S. Department of Energy (DOE) is preparing a proposal to construct, operate and monitor, and eventually close a repository at Yucca Mountain in Nye County, Nevada, for the geologic disposal of spent nuclear fuel (SNF) and high-level radioactive waste (HLW). As part of this effort, DOE has prepared a viability assessment and an assessment of potential consequences that may exist if the repository is not constructed. The assessment of potential consequences if the repository is not constructed assumes that all SNF and HLW would be left at the generator sites. These include 72 commercial generator sites (three commercial facility pairs - Salem and Hope Creek, Fitzpatrick and Nine Mile Point, and Dresden and Morris - would share common storage due to their close proximity to each other) and five DOE sites across the country. DOE analyzed the environmental consequences of the effects of the continued storage of these materials at these sites in a report titled Continued Storage Analysis Report (CSAR: Reference 1). The CSAR analysis includes a discussion of the degradation of these materials when exposed to the environment.

This document describes the environmental parameters that influence the degradation analyzed in the CSAR. These include temperature, relative humidity, precipitation chemistry ( $\mathrm{pH}$ and chemical composition), annual precipitation rates, annual number of rain-days, and annual freeze/thaw cycles. The document also tabulates weather conditions for each storage site, evaluates the degradation of concrete storage modules and vaults in different regions of the country, and provides a thermal analysis of commercial SNF in storage.

\subsection{Concrete Storage Module Degradation}

Reference 2 developed and documented the degradation mechanisms related to failure of the concrete storage module (CSM). The analysis considered degradation due to exposure to the surrounding environment. In that reference, Failure is defined as the time when precipitation would infiltrate the concrete and reach the SNF or HLW storage canister. The primary cause of failure of surface-mounted concrete structures would be freeze/thaw cycles that caused the concrete to crack and spall (break off in layers), which would allow precipitation to enter the concrete, causing more freeze damage. Freeze/thaw failure (Reference 2) is defined as the time when half of the thickness of the concrete had been cracked and spalled. The freeze-thaw process is discussed in Reference 2. Some regions (e.g., coastal California, Texas, and Florida) essentially would be unaffected by freeze/thaw damage. In these locations the primary failure mechanism would be chlorides in precipitation, which would decompose the chemical constituents of the concrete into sand-like materials. This process would progress more slowly than the freeze/thaw process and is also discussed in Reference 2.

The calculated time for onset of damage and roof collapse at nuclear storage sites are shown on Table 2-1. The analysis includes damage from freeze/thaw and chemical attack. The first three sites (Vogtle, Perry, and Monticello) identified in Table 2-1 were representative of most storage sites in the United States where freezes are experienced. The remaining sites, shown in the table, are those sites with very limited freezing weather. The main cause of damage is from the effects of the freeze/thaw process at the sites. The analysis shows that chemical attack contributes minimally to failure of the concrete storage modules. 
Table 2-1. Haximple information for concrele freeze/haw (times are from loss of institutional control).

\begin{tabular}{|c|c|c|c|c|c|c|c|c|c|c|c|c|}
\hline 1 & 2 & 3 & 4 & 5 & 6 & 7 & 8 & 9 & 10 & 11 & 12 & 13 \\
\hline Localion of Weathering & $\begin{array}{c}\text { Augusla, } \\
\text { GA }\end{array}$ & $\begin{array}{c}\text { Cleveland, } \\
\mathrm{OH}\end{array}$ & $\begin{array}{c}\text { Saint Cloud, } \\
\text { MN }\end{array}$ & $\begin{array}{c}\text { Sacramento, } \\
\text { CA }\end{array}$ & $\begin{array}{c}\text { Santa Maria, } \\
\text { CA }\end{array}$ & $\begin{array}{c}\text { Eureka, } \\
\text { CA }\end{array}$ & $\begin{array}{l}\text { Victoria, } \\
\text { TX }\end{array}$ & $\begin{array}{c}\text { Tampa, } \\
\mathrm{FL}\end{array}$ & $\begin{array}{l}\text { Phoenix, } \\
\text { AZ }\end{array}$ & $\begin{array}{l}\text { West Palm } \\
\text { Beach, FL }\end{array}$ & $\begin{array}{c}\text { Miami, } \\
\text { FL }\end{array}$ & $\begin{array}{c}\text { San Diego \& } \\
\text { Los Angeles, CA }\end{array}$ \\
\hline Reaclor & Voglle & Perry & Monticello & $\begin{array}{c}\text { Pancho } \\
\text { Seco }\end{array}$ & $\begin{array}{l}\text { Diablo } \\
\text { Canyon }\end{array}$ & $\begin{array}{c}\text { Humbold } \\
\text { Bay }\end{array}$ & $\begin{array}{l}\text { South } \\
\text { Texas }\end{array}$ & $\begin{array}{l}\text { Crystal } \\
\text { River }\end{array}$ & $\begin{array}{l}\text { Palo } \\
\text { Verde }\end{array}$ & SI. Lucie & $\begin{array}{l}\text { Turkey } \\
\text { Point }\end{array}$ & San Onolre \\
\hline $\begin{array}{l}\text { Precipilation (inches) during } \\
\text { monlths with temperature } \\
\text { falling } \\
\text { below freezing }\end{array}$ & 25 & 22.6 & 15.8 & 14.4 & 11.97 & 28.53 & 10.2 & 12 & 3.9 & 11.6 & 3.8 & $\begin{array}{l}\text { No Prec with } \\
\text { freezing }\end{array}$ \\
\hline
\end{tabular}

\begin{tabular}{|c|c|c|c|c|c|c|c|c|c|c|c|c|}
\hline Freezing (days/year) & 56.2 & 125.5 & 176.9 & 17.4 & 20.1 & 5 & 12.2 & 3.6 & 7.7 & 0.8 & 0.2 & no lreezing \\
\hline $\begin{array}{l}\text { Weathering Index (day- } \\
\text { inches) }\end{array}$ & 1,405 & 2,832 & 2,788 & 251 & 241 & 143 & 124 & 43 & 30 & 9 & 1 & Intinity \\
\hline $\begin{array}{l}\text { Time to Onsel of damage } \\
\text { (penetration reached 3"). } \\
\text { yrs. }\end{array}$ & 18 & 9 & 9 & 100 & 104 & 175 & 200 & 580 & 835 & 2,680 & 32,500 & Infinity \\
\hline $\begin{array}{l}\text { Time to fool Collapse, yrs. } \\
\text { (Freeze/thaw lailure only) }\end{array}$ & 160 & 79 & B1 & 898 & 935 & 1,577 & 1,800 & 5,200 & 7,510 & 24,200 & 293,000 & Infinily \\
\hline $\begin{array}{l}\text { Time to Roof Collapse, yrs. } \\
\text { (All lailure modes } \\
\text { combined) }\end{array}$ & 159 & $\begin{array}{l}2.7 \\
78.7\end{array}$ & 80.5 & 832 & $\begin{array}{l}\text { Wfisis } \\
870\end{array}$ & $\frac{1}{1.380}$ & 1,550 & 3,550 & 4,500 & $\frac{3+3 x}{7,600}$ & $\frac{10,700}{10}$ & $\frac{11,000}{11,00}$ \\
\hline $\begin{array}{l}\% \text { Failure contributed by } \\
\text { Freeze/thaw degradiation }\end{array}$ & 99.4 & 99.6 & 99.4 & 92.6 & 93.0 & 87.5 & 86.1 & 68.3 & 59.9 & 31.4 & 3.7 & 0.0 \\
\hline
\end{tabular}

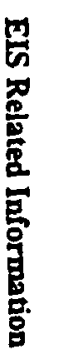


In fact when no freeze/thaw damage occurs to the concrete storage modules, the concrete could be expected to last 11,000 years.

As described in the summary of Reference 2, "Underground concrete structures are expected to last longer because they are in a more benign environment. For example, the Glass Waste Storage Facility at Savannah River Site (SRS) near Augusta, GA was evaluated, and the concrete within it was found to last about 3,000 years. However, the expected failure sequence for that facility may not be concrete failure. The weather protection portion of that facility (i.e., the roof) should protect its contents for 150 years until that cover is lost. At that time, the contents of the vault (in this case the High-Level Waste as a borosilicate glass in a stainless steel canister) will be exposed to precipitation. From 150 to 3,000 years the concrete vault is expected to serve as a tub, and the engineered barrier of the canister and leach resistance of the glass must provide protection. (The protection provided by the waste canister and the waste itself were not evaluated in Reference 2.)

Since the chemical degradation of underground facilities has been previously identified in Reference 2 , that analyses is summarized in Section 2.2.1 of this report. Section 2.2.2 has five subparts and describes chemical degradation for surface facilities and determine the rate of degradation.

The following sections discuss in more detail the freeze-thaw and chemical attack processes, describe the input data and sources used, and present results of the analysis. Section 2.1 discusses concrete degradation by freeze-thaw phenomenon. Concrete degradation by chemical attack (sulfate attack, magnesium attack, calcium leaching, carbonation, chloride penetration, and rebar corrosion, is discussed in Section 2.2. Sections 3.0 through 5.0 provide the source and use of precipitation data, precipitation chemistry (concentrations of chemicals in rainfall), and relative humidity data, respectively. Section 6.0 discusses degradation of engineered barriers (concrete casks and stainless steel containers) as affected by the temperature conditions at the nuclear reactor sites.

\subsection{Concrete Degradation from Freeze/Thaw}

Concrete degradation due to freeze/thaw depends on the number of days the temperanre is below freezing and the amount of precipitation on these days. Table 2-2 shows the number of days in each month with temperature below freezing and the amount of precipitation that occurred during these months. This information was obtained from Local Climatological Data assembled by the National Climatic Data Center in Asheville, NC (Reference 3) using a minimum of 30 years of data. For each site where SNF currently is stored and for all of the DOE site storing DOE-SNF and DOE-HWL, the weathering index (day-inches) was calculated by multiplying the number of freezing days times the winter precipitation expressed in inches. As described in Reference 2, the assumed freeze/thaw damage uses this weathering index. The weathering index also is provided in Table 2-2 for each site. Reference 2 defines the following concrete failure stages:

- Onset of damage is defined as penetration of the outer concrete surface to a depth 3 inches.

- Complete failure is defined as perietration of concrete to depth 50 percent of its thickness, which is assumed to be loss of weather protection afforded by the concrete.

The calculated time for onset of damage and roof collapse (years of weather protection) are shown on Table 2-2. If several cities are located near a single site, and no meteorological station was available near the site with long-term weather data, the site data were estimated from the average data of the several cities surrounding the site. 
Table 2-2. Commercial reactor freeze/thaw data (1 of 13).

Reacior silcs number

Record (ycturs)

30
Vogl

$\mathbf{3 0}$

Peity Montecello

Montectlo

Alugustial GA Cleveland Saim Cloud

Freceing (days/month)

Jume

Inly

August

Sepplemilut

Oxtoluer

Novemiler

Decemular

Jasiualy

Fibruary

Maucli

April

ล) May

Toulal

Precipitalion

5 Janc

July

August

Seplcumber

Ocluter

Novesuler

Januily

Fubruiny

March

April

Miay

Total Winter Precip.

Iovlal - end Mo

Inidjusted Weallicijug

Onsel af

Dianage, y?

Roof Collapsi

Yeins

Ohio

Michizan!

Columbia

South Carolina

Average

California

Los Angules
California

Onofre

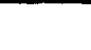

\begin{tabular}{c|c}
5 \\
Sun Onufre \\
Average \\
$\begin{array}{c}30 \\
\text { Si Lucie } \\
\text { West Palun Beach } \\
\text { Flurida }\end{array}$
\end{tabular}

爱

1

2.48
3.4
4.05
4.27
4.65
3.31
2.5
18.85
1.40 .5
17.8
160

\begin{tabular}{rr}
0.8 & 2.8 \\
6.7 & 12. \\
14.2 & 24.8 \\
16.7 & 27. \\
12.5 & 24.3 \\
4.7 & 2 \\
10.6 & 9 \\
& 0. \\
56.2 & 125 \\
\hline
\end{tabular}

$\begin{array}{r}2.8 \\ .5 \\ .8 \\ .9 \\ .3 \\ .3 \\ .9 \\ \hline\end{array}$

2.5

1.8
1.3
26.2
30.6
31
27.6
27.7
15.9
3.1
176

\begin{tabular}{r|r}
1.8 \\
1.3 \\
26.2 \\
30.6 \\
31 \\
27.6 \\
27.7 \\
15.9 \\
3.1 \\
76.9 \\
\hline
\end{tabular}

$\begin{array}{r} \\ 1.2 \\ 7.5 \\ 14.7 \\ 17.3 \\ 13.1 \\ 5.8 \\ 0.9 \\ 60.5 \\ \hline\end{array}$

$\begin{array}{r} \\ 0.9 \\ 6.6 \\ 15.4 \\ 19 \\ 15.3 \\ 7.2 \\ 1 \\ 65.4 \\ \hline\end{array}$

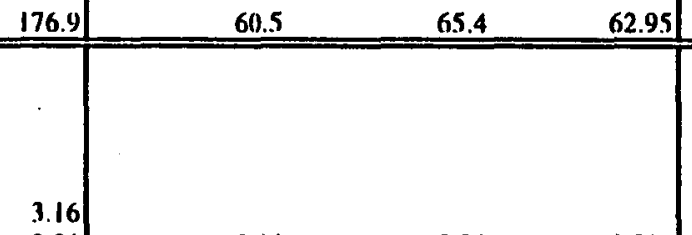

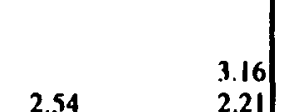

$\begin{array}{rr}2.84 & 2.54 \\ 2.48 & 3.17 \\ 3.4 & 3.09 \\ 4.05 & 2.04 \\ 4.27 & 2.19 \\ 4.65 & 2.91 \\ 3.31 & 3.14 \\ & 3.49 \\ 2.5 & 22.57\end{array}$

2.21
1.27
0.83
0.74
0.63
1.41
2.35
3.16
1.5 .76

2.788
9.0

\begin{tabular}{|c|c|c|c|c|c|c|}
\hline 2.21 & 3.04 & 3.99 & 3.515 & 0.37 & 0.34 & \\
\hline 1.27 & 2.9 & 3.6 .5 & 3.275 & 1.45 & 1.75 & \\
\hline 0.8 .3 & 3.59 & 4.14 & 3.86 .5 & 1.57 & 1.66 & \\
\hline 0.74 & 4.42 & 4.1 & 4.26 & 1.8 & 2.4 & \\
\hline 0.63 & 4.12 & 4.41 & 4.26 .5 & 1.53 & 2.51 & \\
\hline 1.41 & 4.82 & 5.39 & 5.105 & 1.77 & 1.98 & \\
\hline 2.35 & 3.28 & 3.86 & 3.57 & 0.79 & 0.72 & \\
\hline 3.16 & & & & & & \\
\hline 15.76 & 26.17 & 29.54 & 27.855 & 9.28 & 11.36 & 10.32 \\
\hline & 22.89 & 25.68 & 24.28 .5 & & & \\
\hline 2.788 & 1,583 & 1,932 & $1,7.57 .600 .5$ & ) & & \\
\hline 8.0 & & & 14.2 & & & \\
\hline 81 & & & 128 & & & \\
\hline
\end{tabular}

\begin{tabular}{|c|c|c|c|c|c|c|}
\hline 2.21 & 3.04 & 3.99 & 3.515 & 0.37 & 0.34 & \\
\hline 1.27 & 2.9 & 3.65 & .3.275 & 1.45 & 1.75 & \\
\hline 0.8 .3 & 3.59 & 4.14 & 3.865 & 1.57 & 1.66 & \\
\hline 0.74 & 4.42 & 4.1 & 4.26 & 1.8 & 2.4 & \\
\hline 0.63 & 4.12 & 4.41 & 4.26 .5 & 1.53 & 2.51 & \\
\hline 1.41 & 4.82 & 5.39 & 5.105 & 1.77 & 1.98 & \\
\hline 2.35 & 3.28 & 3.86 & 3.57 & 0.79 & 0.72 & \\
\hline 15.76 & 26.17 & 29.54 & 27.855 & 9.28 & 11.36 & 10.32 \\
\hline & 22.89 & 25.68 & 24.28 .5 & & & \\
\hline 88 & $1,58.3$ & 1,932 & $1,757.6005$ & 0 & & \\
\hline 9.0 & & & 14.2 & & & \\
\hline 81 & & & 128 & & & \\
\hline
\end{tabular}


Table 2-2. Commercial reactor freeze/thaw dala (2 of 13).

Reactor site numitur

Record (ycius)

30)

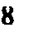

Maine Yunkes

Palo Verde

30

Threc Mi Island

Ponland. Me

Phixunix
Arizonia

Middlitown

Frtecing (days/month)

JuIn

July

Alugust

Oelolixi

Noveculder

Decentiber

Jamuary

Fitbruary

March

As April

5 Mily

Tolal

Precipitalion

Jume

3. July

Alugust

Sejpleititu:

Oclober

Novenilxer

Decenthei

Jantuary

Fishruary

March

April
Miny

Tolal Winter Precip.

Tulial - End MO

Unialjosted Weallneting

Index, day-incless

Onsel of

Dauntage, yr

Rour C cullips

Yearls

3.109

3.9
5.17

5.17
4.55

3.53

3.33

$\mathbf{3 . 6 7}$

4.08

3.63

34.95

Penusylvania

Aikansis

Arkausas

Average

erage

Illinois

11,12,

\& 13

30

La Sille

Braidwood

nois

30

5.407

8.34 .6

7.512

0.66
1
0.67
0.68
0.88

3.89
30
8.34 .6
$7.5+z$

3.68

3.99

3.03

1.9

3.95

3.97

23.12

21.98

2,270

1.813

13.8

124

120 
Table 2-2. Commercial reactor freeze/lhaw data (4 of 13).

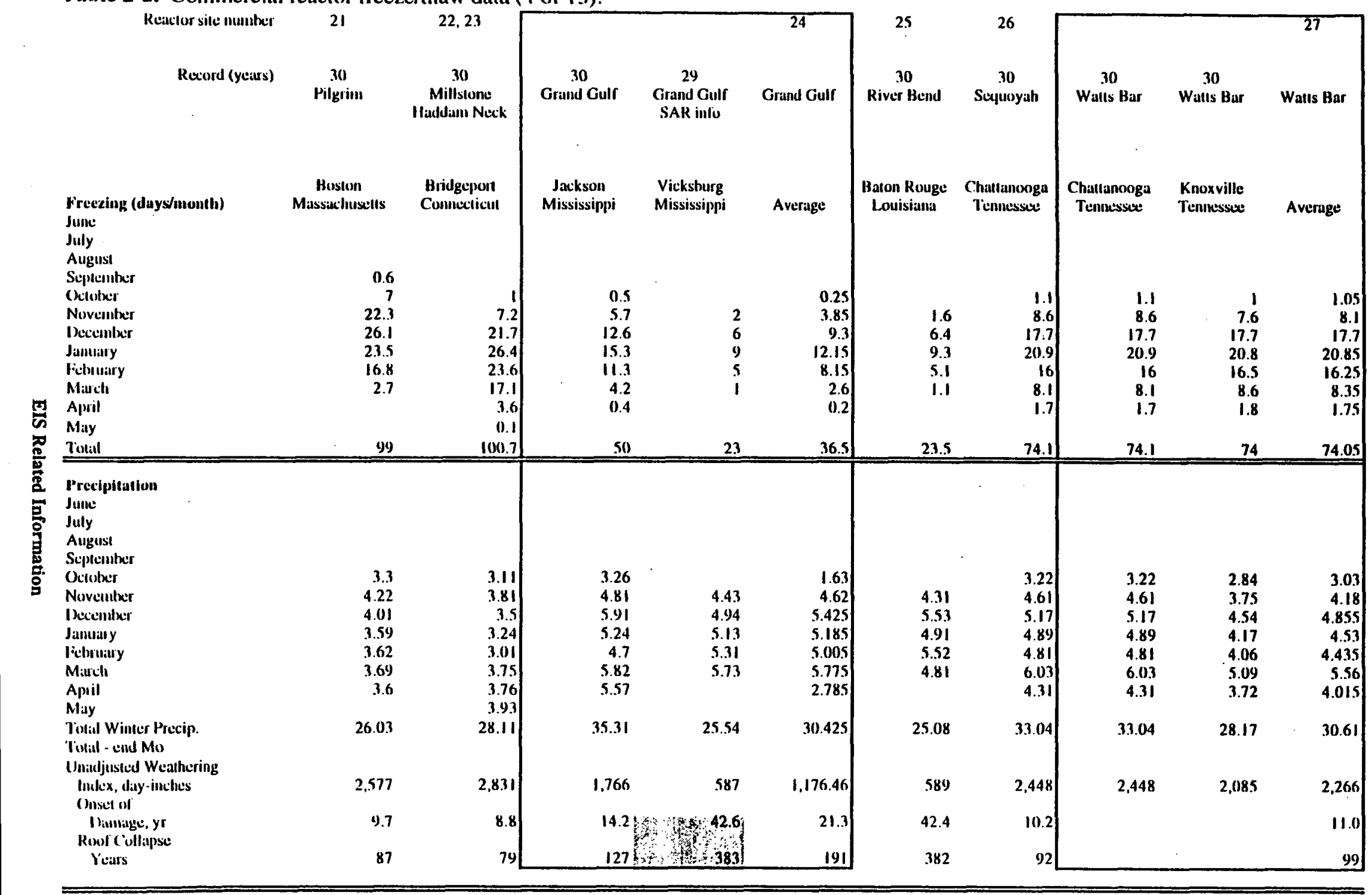


Table 2-2. Commercial reaclor freeze/thaw data (5 of 1.3).

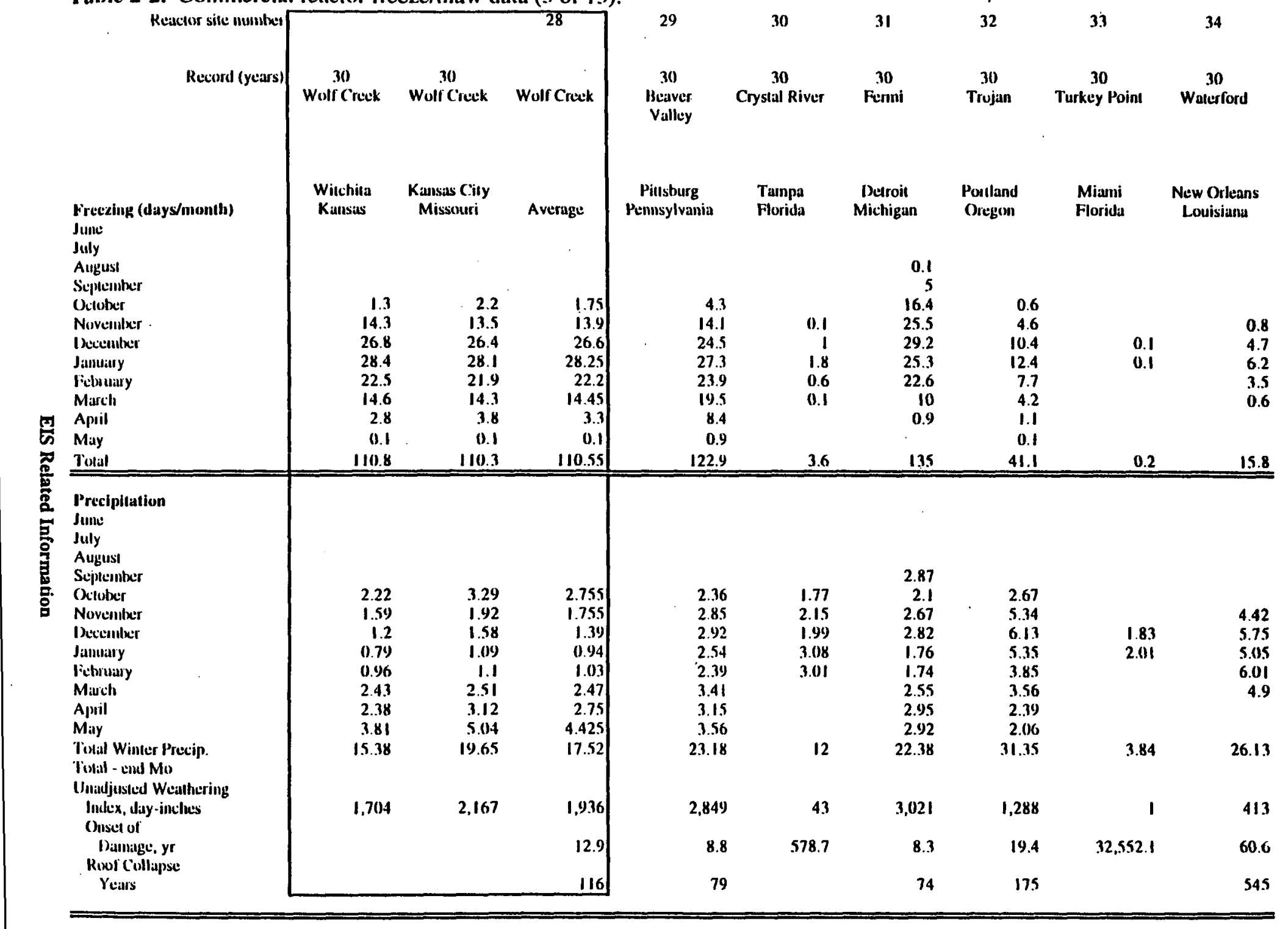


Table 2-2. Commercial reactor freeze/thaw data (6 of 13).

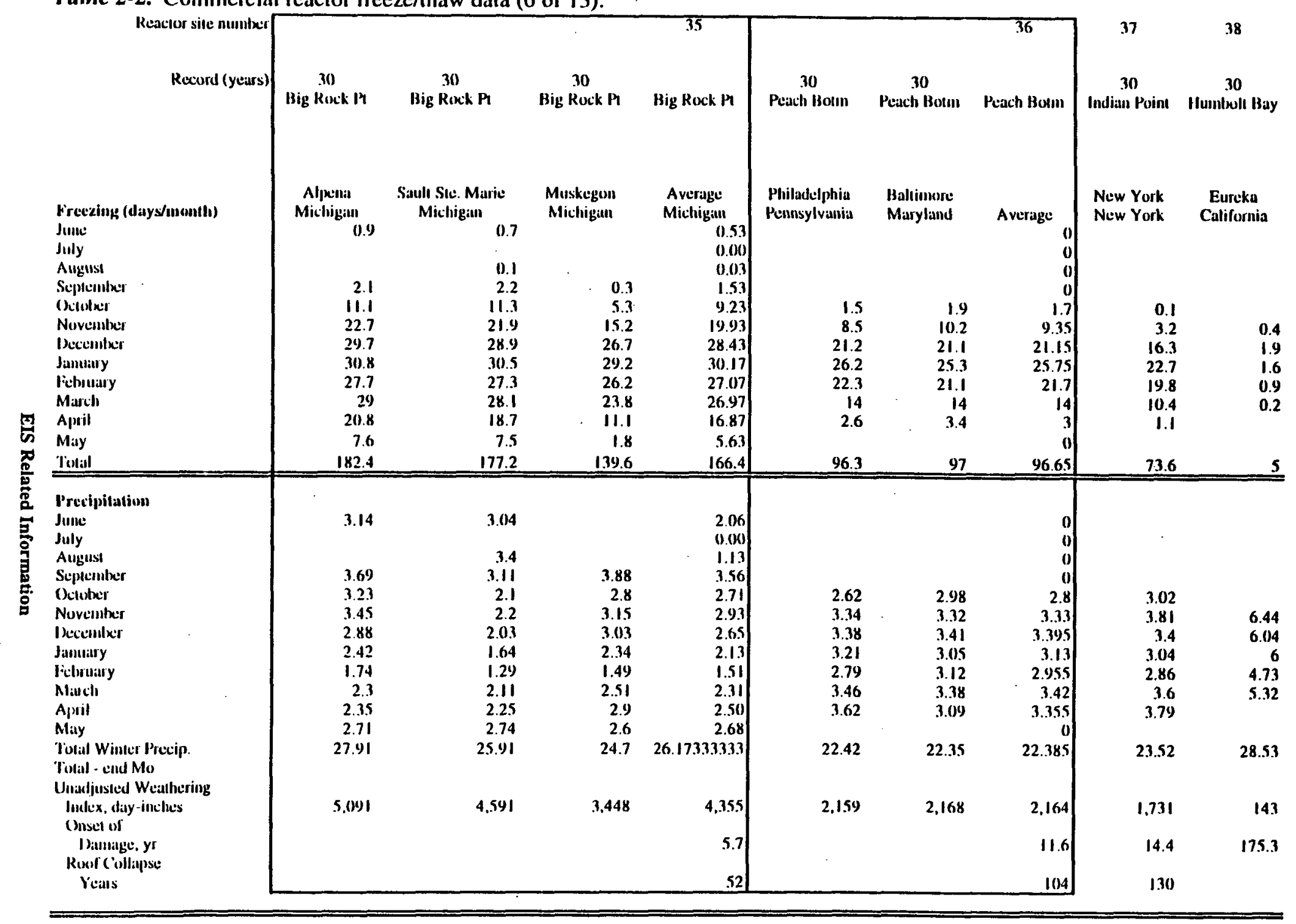


Table 2-2. Commercial reactor freeze/thaw data (7 of 13).

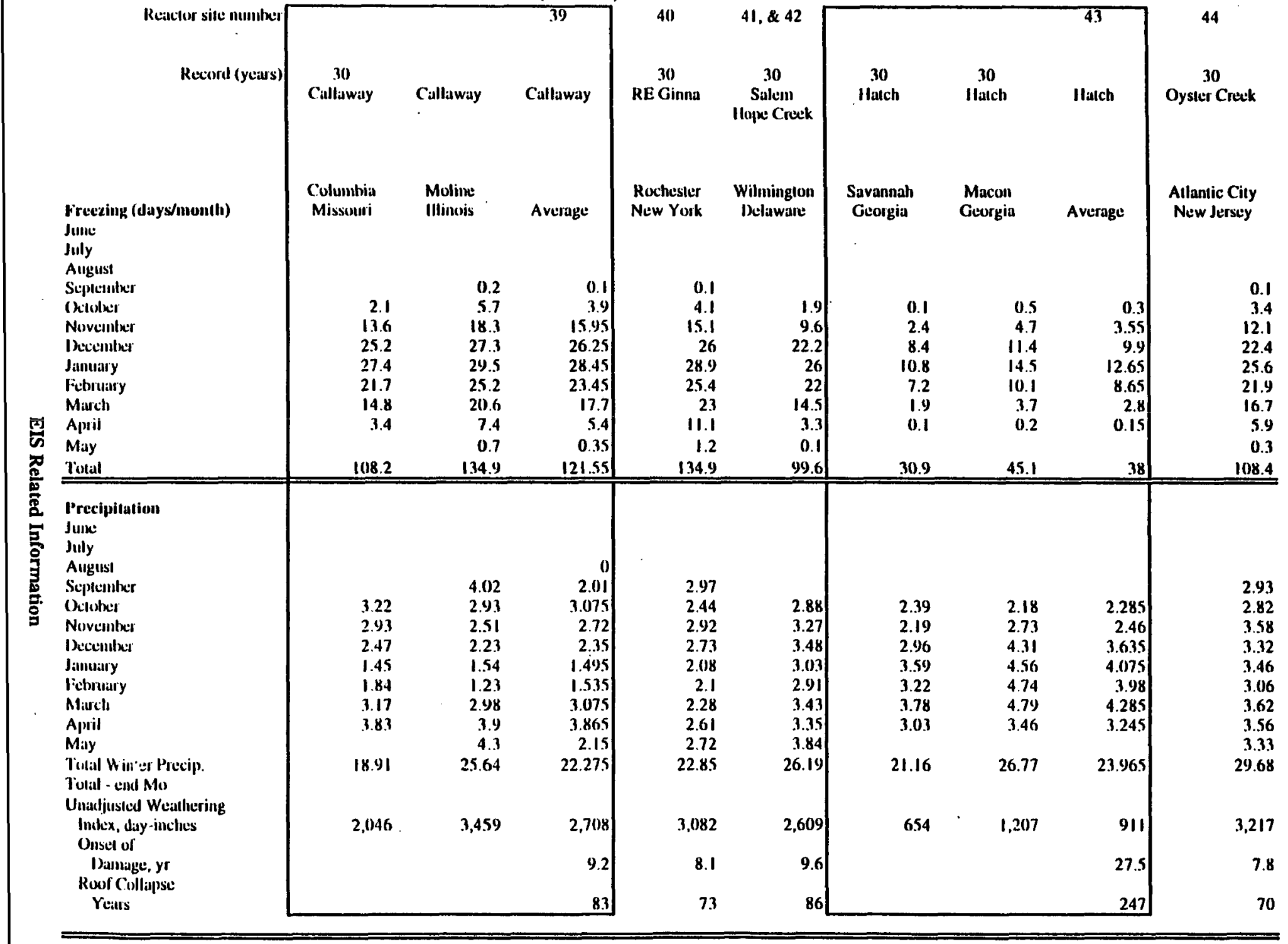


Table 2-2. Commercial reactor freeze/thaw data (8 of 13).

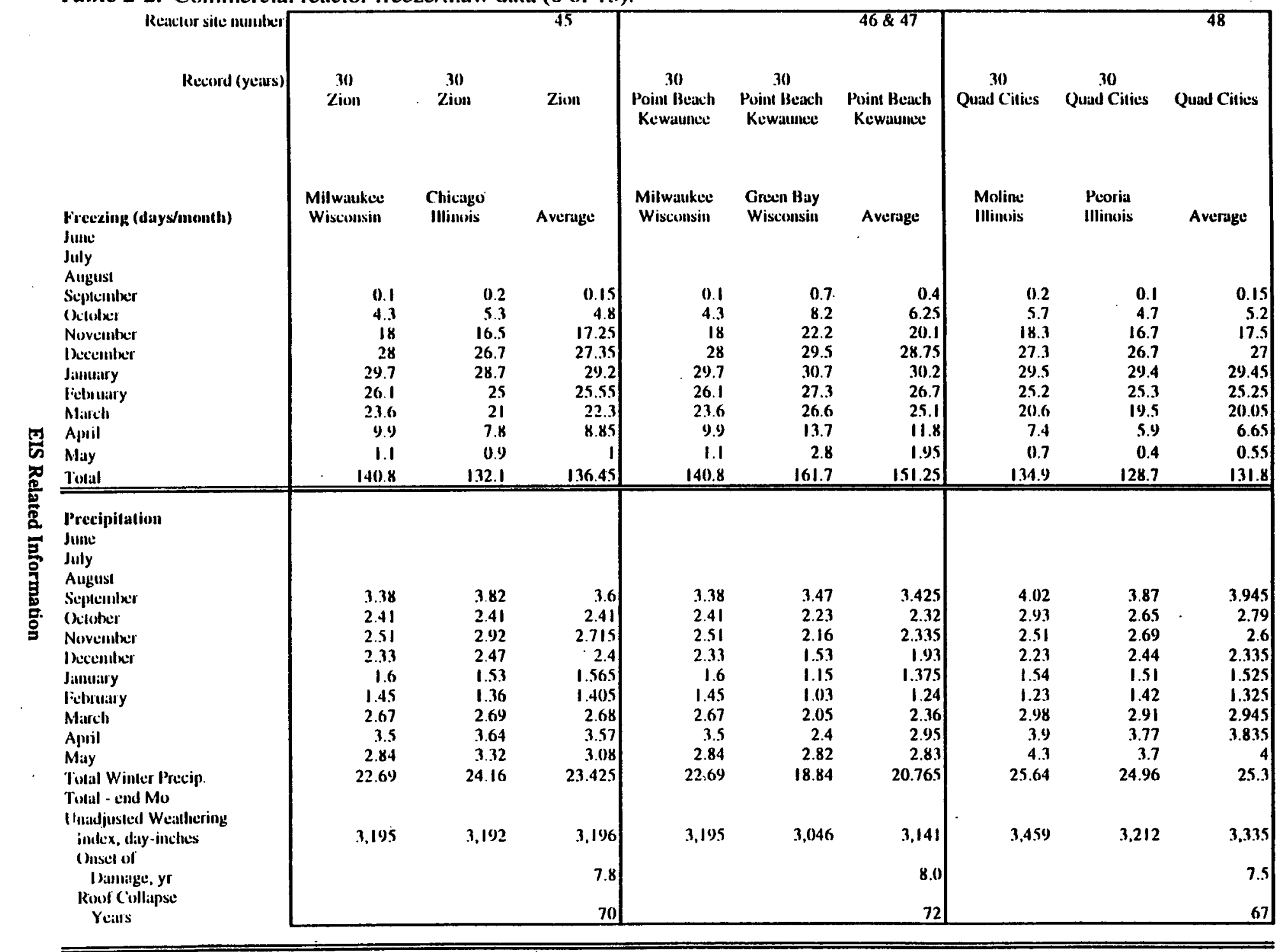


Table 2-2. Commercial reactor freeze/thaw data (9 of 13).

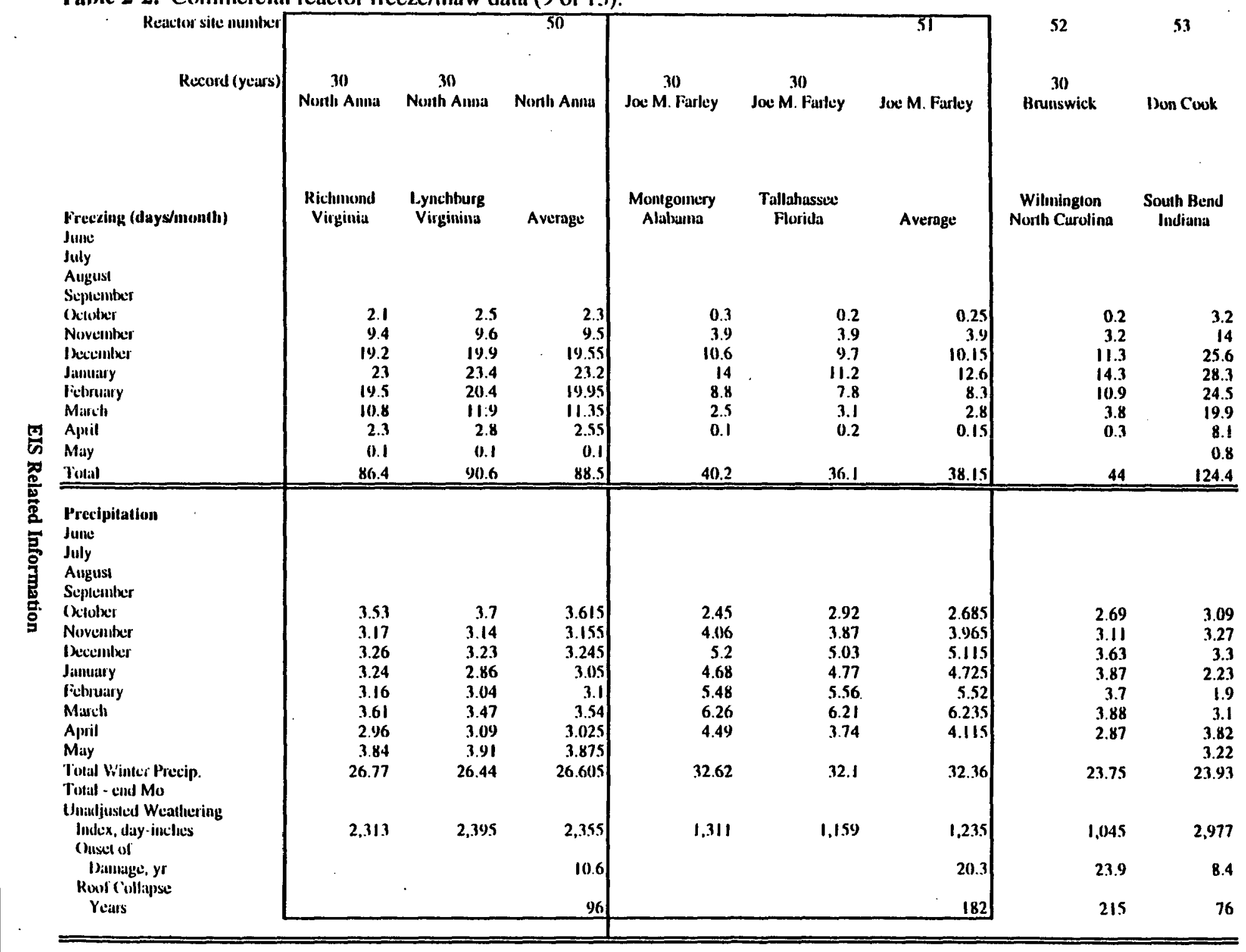


Table 2-2. Commercial reactor freeze/lhaw data ( 10 of 13).

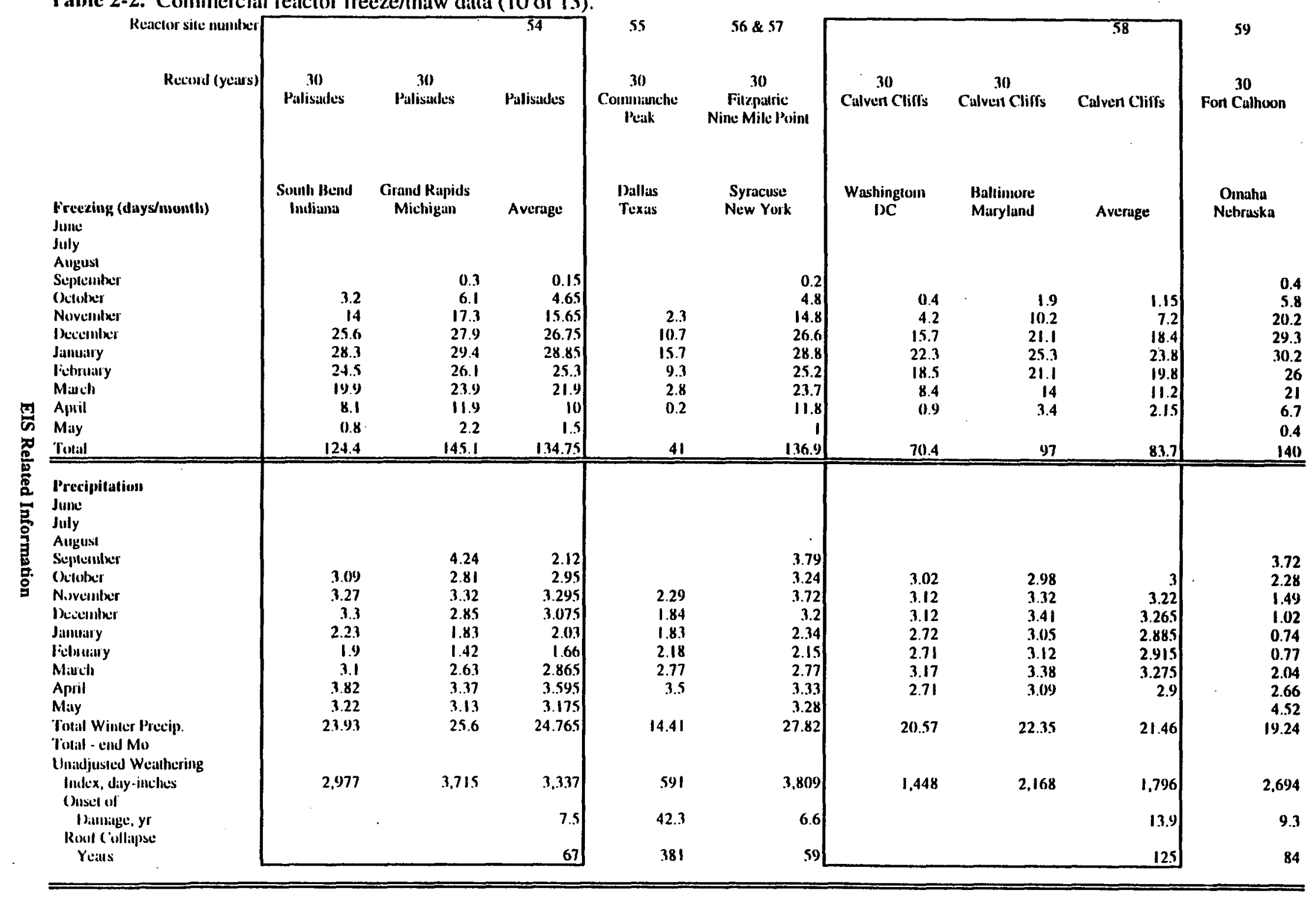


Table 2-2. Commercial reactor freeze/lhaw data (12 of 13).

Recordl (years)

68

69

70

71

$\begin{array}{cc}30 & 30 \\ \text { Shearsoun } & \text { Limesick }\end{array}$

30

Yauket

30
Seiabrook

30

Surry

Ralcigh Philacklphia Albany Porlland North Ciuslima

Maine

Norfolk

Virginia

Freceing (days/month)

Juine

July

Augusi

Sciplinilur

Octules

Novelniser

Decioniluer

Jantikiny

Fiehruary

Mincilı

Ap Apil

Mayy

Toral

Irecipitation

Junc

August

5 Alugust

E. Oclutur

Novesule:

Decimber

Jamuary

Jichuminy

Mincli

Aprit

Tutal Winter Precip.

Tintul - cond Mo

Itatajusled Wealloring

lualex, day-inches

(Misct of

Dimlinge, yr

Rouf Colliapse

Yeals

$\begin{array}{rrr} & & 2.86 \\ 2.98 & 2.62 & 2 . \\ 3.24 & 3.34 & 3 . \\ 3.48 & 3.38 & 2 . \\ 3.69 & 3.21 & 2.36 \\ 3.77 & 2.79 & 2.2 \\ 2.59 & 3.46 & 2 . \\ 3.92 & 3.62 & 2 . \\ 26.53 & & 3.4\end{array}$

$\begin{array}{ll}2.95 & 3.09\end{array}$

3.2 .3

2.93
2.36

2.36

2.93

2.99

3.41
25.9

0.8

$\begin{array}{rr}8.4 & 8.6 \\ 8.1 & 19.3\end{array}$

28.9

29.9
9

$\begin{array}{ll}2.4 & 25.2 \\ 13 & 13.5\end{array}$

$1.7 \quad 2$

56.2

72

73

$30-50$

Susquchana

Wisthinglon

Nuclual Power

Wilkes-Harre

Scranton

PNNL I1471

Hauford Site

G.SAR-0000
SRS

$\begin{array}{lll}3.9 & 3.15 & 2.79\end{array}$

$\begin{array}{lll}5.17 & 2.85 & 3.06\end{array}$

$\begin{array}{lll}4.55 & 3.23 & 2.51\end{array}$

3.53

3.33

3.67

4.08

3.78
3.47

3.7

3.06

23.24

2.1
2.15

2.15
2.55
2.97
3.65

3.65

34.95

21.78

$2,08.5 \quad 2,159$

3.859

5.407

1,306

$\begin{array}{lll}6.5 & 4.6 & 19.1\end{array}$

2,720

$12.0 \quad 11.6$

58

42

172

83

4.55

\begin{tabular}{|c|c|c|c|}
\hline 0.39 & 2.49 & & 0.21 \\
\hline 0.91 & 2.6 & 0.24 & 0.43 \\
\hline 1.0.3 & 3.63 & 0.45 & 0.38 \\
\hline 0.79 & 4.17 & 0.92 & 0.4 \\
\hline 1.62 & 4.61 & 0.61 & 0.48 \\
\hline 47 & 5.02 & 0.9 & 0.42 \\
\hline 0.41 & 3.49 & & 0.21 \\
\hline 4.62 & 26.01 & 3.12 & 2.53 \\
\hline 494 & 970) & 119 & 8.3 \\
\hline (2). & 25.8 & 210.9 & 301.3 \\
\hline & 2.32 & 1898 & 2711 \\
\hline
\end{tabular}


Table 2-2. Commercial reaclor freeze/thaw data (13 of 13).

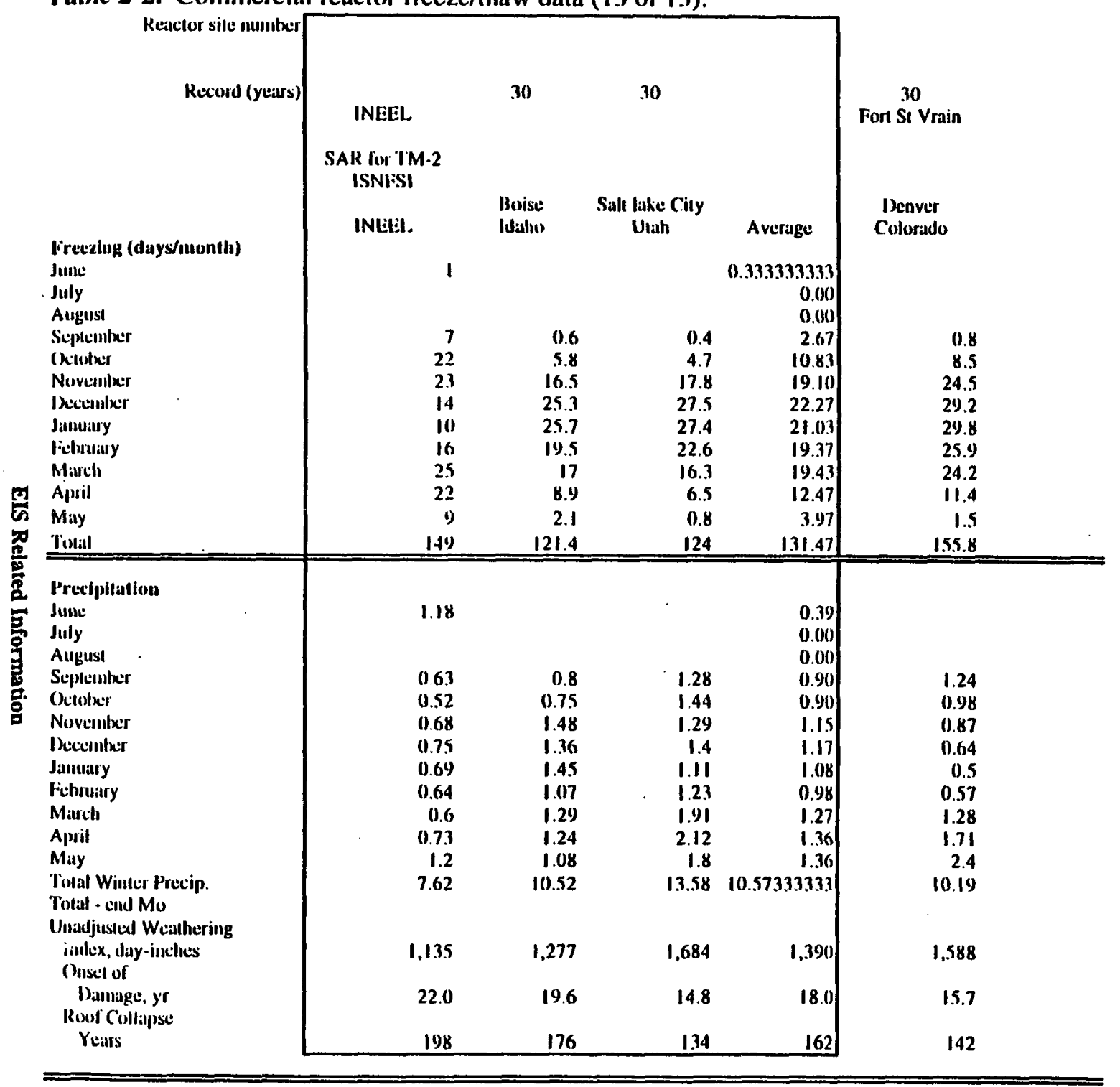




\subsection{Concrete Degradation Aboveground Storage Facilities from Chemical Attack Analysis}

For degradation of concrete resulting from chemical attack (from chemicals present in precipitation), the following processes were evaluated: sulfate and magnesium attack, calcium leaching, carbonation, chloride penetration, and rebar corrosion. To determine the rate at which chemical reactions would occur, it was necessary to determine the chemical composition of the concrete (Reference 4). The chemical concentration was determined from calculating the composition of each chemical in several types of concrete commonly utilized in construction. The density of the concrete was assumed to be 2.7 grams $/ \mathrm{cm}^{3}$.

The chemical (i.e., chlorides, etc.) composition of the precipitation was taken from the data associated with the Savannah River Site (SRS) near Barnwell, South Carolina. The precipitation chemistry data (Table 2-3) were obtained by daily sampling although only the yearly averages for 1996 and 1997 are listed.

Table 2-3. Precipitation chemistry for Bamwell, South Carolina.

\begin{tabular}{lll}
\hline & \multicolumn{2}{c}{ Average for year } \\
\cline { 2 - 3 } \multicolumn{1}{c}{ Chemistry } & 1996 & 1997 \\
\hline PH & 4.542 & 4.588 \\
Fluoride, $\mu \mathrm{g} / \mathrm{mg}$ & 0.062 & 0.018 \\
Chloride & 0.947 & 0.455 \\
Bromine & 0.000 & 0.000 \\
Nitrate & 1.072 & 0.830 \\
Phosphate & 0.000 & 0.000 \\
Sulfate & 1.681 & 1.435 \\
Sodium & 0.320 & 0.235 \\
Ammonium & 0.134 & 0.181 \\
Potassium & 0.000 & 0.000 \\
Calcium & 0.021 & 0.054 \\
\hline
\end{tabular}

a. Information from Reference 5.

b. Chemical units are $\mu \mathrm{g} / \mathrm{mg}$; $\mathrm{pH}$ has no units.

The concrete degradation processes are discussed in Reference 2. The formulae used in Sections 2.2.2.1 through 2.2.2.5 analyze the rate chemical attack on surface concrete storage modules.

\subsubsection{CONCRETE DEGRADATION FOR UNDERGROUND CONCRETE VAULTS (FROM SECTION 4.2.2 OF REFERENCE 2)}

An analysis of concrete damage indicates that the predominate failure mechanism for an underground concrete vault is a combination of physical, chemical, and mechanical forces. Physical and mechanical degradation processes that produce cracking are of primary concern because the permeability increases and shielding is potentially lost. The chemistry of groundwater would affect the degradation of the underground facility. The major sources of sulfate and magnesium in SRS groundwater are from weathering of rock minerals by rainfall. Concentrations of sulfate and magnesium in groundwater at SRS are very low. Sulfate concentrations range from 0.27 to $15 \mathrm{ppm}\left(2.81 \times 10^{-6}\right.$ to $\left.1.56 \times 10^{-4} \mathrm{~mol} / \mathrm{L}\right)$ with a mean and median of 3.66 and $2 \mathrm{ppm}\left(3.81 \times 10^{-5}\right.$ and $\left.2.08 \times 10^{-5} \mathrm{~mol} / \mathrm{L}\right)$, respectively. Magnesium concentrations range from 0.14 to $8 \mathrm{ppm}\left(5.76 \times 10^{-6}\right.$ to $\left.3.29 \times 10^{-4} \mathrm{~mol} / \mathrm{L}\right)$, with a mean and medium of 2.28 and $1.5 \mathrm{ppm}\left(9.37 \times 10^{-5}\right.$ and $\left.6.17 \times 10^{-5} \mathrm{~mol} / \mathrm{L}\right)$, respectively. The sum of $\mathrm{Mg}$ and $\mathrm{SO}_{4}$ range from 
0.57 to $18.5 \mathrm{ppm}\left(1.51 \times 10^{-5}\right.$ to $\left.3.77 \times 10^{-4} \mathrm{~mol} / \mathrm{L}\right)$ with a mean and median of 5.94 and $4.95 \mathrm{ppm}$ $\left(1.32 \times 10^{-4}\right.$ and $\left.1.08 \times 10^{-4} \mathrm{~mol} / \mathrm{L}\right)$, respectively (Reference 2 ).

The principal chemical processes that may disrupt the integrity of concrete structures are carbonation, calcium hydroxide leaching, and rebar corrosion. Each of these is discussed in Appendix B of Reference 2. Each was evaluated for the operating floor (or roof of vault) and the walls and floor of the vault at 1,000 and 10,000 years. (See Table 2-4 for results of this analysis.) The major failure was shown to be cracking and collapse of the operating floor after 3,200 years. Freeze/thaw damage was not evaluated because it was considered a minor consequence for subsurface structures, especially at SRS.

Table 2-4. Concrete damage in underground concrete facilities.

\begin{tabular}{|c|c|c|}
\hline \multicolumn{3}{|c|}{ Expected depth of concrete damage } \\
\hline Degradation mechanism & 1,000 years damage & 10,000 years damage \\
\hline Sulfate and magnesium attack & $1 \mathrm{~cm}$ & $5 \mathrm{~cm}$ \\
\hline Carbonation & $\begin{array}{l}\text { Reflected in reinforcing bar } \\
\text { corrosion }\end{array}$ & $\begin{array}{l}\text { Reflected in reinforcing bar } \\
\text { comosion }\end{array}$ \\
\hline Calcium hydroxide leaching & $5 \mathrm{~cm}$ & $23 \mathrm{~cm}$ \\
\hline \multicolumn{3}{|c|}{ Time to cracking of operating floor from stress increases from concrete loss (years) } \\
\hline Concrete loss & 1,600 & \\
\hline \multicolumn{3}{|c|}{ Time to roof collapse (years) } \\
\hline $\begin{array}{l}\text { Reinforcing bar corrosion (average } \\
\text { loss or bar cross sectional area at } \\
1,000 \text { year }--40 \% \text { ) }\end{array}$ & 3,200 & \\
\hline
\end{tabular}

\subsubsection{CONCRETE DEGRADATION FOR SURFACE CONCRETE FACILITIES}

The section has five parts that describe chemical degradation mechanisms for surface concrete facilities resulting from long-term exposure to precipitation. Both the description of the surface concrete facilities and the degradation mechanism are discussed in Reference 2 . These five subsections apply the mechanisms to the concrete failure.

\subsubsection{Sulfate and Magnesium Attack}

The rate of surface loss due to sulfate and magnesium attack was calculated using the following formula:

$\mathrm{X}=0.55 \mathrm{C}_{\mathrm{s}}\left(\mathrm{Mg} \mathrm{2}++\mathrm{SO}_{4} 2-\right) \mathrm{t}$

where

$$
\begin{aligned}
& \mathrm{X}=\text { distance of corrosion into concrete }(\mathrm{cm}) \\
& \left.\mathrm{C}_{\mathrm{S}}=\mathrm{C}_{3} \mathrm{~A} \text { (concrete gel) concentration in solid (mole } / \mathrm{cm}^{3}\right) \\
& \mathrm{C}_{\mathrm{mg}}=\mathrm{Mg} \text { concentration in solution (mole/liter) } \\
& \mathrm{C}_{\mathrm{SO}_{4}}=\mathrm{SO}_{4} \text { concentration in solution (mole/liter) } \\
& \mathrm{t}=\text { time }(\mathrm{s})
\end{aligned}
$$

The amount of concrete damaged due to this sulfate and magnesium attack is shown in the second column of Table 2-5. As can be seen from this table, the sulfate and magnesium attack is very low. 


\subsubsection{Calcium Hydroxide Leaching}

Where concrete is exposed to water, constituents in the concrete are leached. Alkalis are leached first, followed by calcium hydroxide. This process can be described in four stages:

1. Initially, the $\mathrm{pH}$ of standard concrete is approximately 13 due to the presence of alkali metal oxides and hydroxides. These alkali metals leach first.

2. After the alkali metals are leached, the $\mathrm{pH}$ is controlled at $\mathbf{1 2 . 5}$ by solid calcium hydroxide. Free (not bound by $\mathrm{C}-\mathrm{S}-\mathrm{H}$ gel) calcium hydroxide is leached first.

3. Following loss of free calcium hydroxide, calcium hydroxide is leached at a slower rate from the $\mathrm{C}-\mathrm{S}-\mathrm{H}$ gel. The $\mathrm{C}-\mathrm{S}-\mathrm{H}$ gel dissolves incongruously, while the $\mathrm{pH}$ drops to 10.5 and the calcium to silicon ratio drops to 0.85 .

4. The $\mathrm{pH}$ is held to 10.5 by congruent dissolution of the C-S-H gel.

Ingress of water onto the concrete surface provides a pathway for leaching of soluble components from the concrete. This leaching of calcium hydroxide from the concrete leads to loss of strength. The rate of leaching was estimated using numerical models shown below that assumed concrete-controlled and geology-controlled leaching, respectively:

$$
\mathrm{X}_{\mathrm{c}}=\left(2 \mathrm{D}_{\mathrm{i}} \frac{\mathrm{C}_{\mathrm{i}}-\mathrm{C}_{\mathrm{gw}}}{\mathrm{C}_{\mathrm{s}}} \mathrm{t}\right)^{1 / 2},
$$

and

$$
X_{G}=2 \phi \frac{C_{i}-C_{g w}}{C_{S}}\left(\frac{R_{d} D_{E} t}{\pi}\right)^{1 / 2}
$$

where,

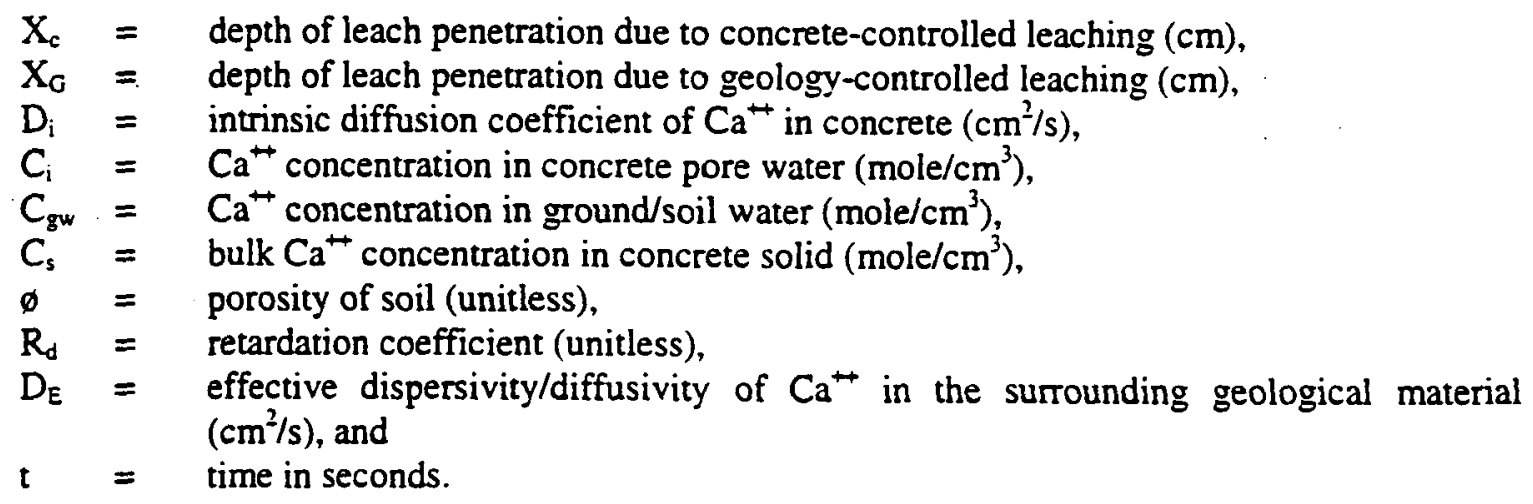

The rate of penetration of concrete is shown in the third column of Table 2-5. 
Table 2-5. Concrele degradation (inches) - no freeze/lhaw degradation.

\begin{tabular}{|c|c|c|c|c|c|}
\hline $\begin{array}{l}\text { Time, } \\
\text { Years }\end{array}$ & $\begin{array}{c}\text { Sullale \& } \\
\text { Magnesium } \\
\text { Allack }\end{array}$ & $\begin{array}{l}\text { Calcium } \\
\text { J.eaching }\end{array}$ & Carbonation & $\begin{array}{c}\text { Chloride } \\
\text { Penctration }\end{array}$ & $\begin{array}{c}\text { Tolal } \\
\text { inches of } \\
\text { Degradation }\end{array}$ \\
\hline 10 & 0.002 & 0.030 & 0.0004 & 0.050 & 0.082 \\
\hline 100 & 0.020 & 0.094 & 0.0012 & 0.331 & 0.446 \\
\hline 1,000 & 0.216 & 0.297 & $0.0(0) 39$ & 2.187 & 2.703 \\
\hline $1,50(x)$ & 0.323 & 0.363 & 0.01047 & 3.049 slarts & 3.740 \\
\hline 2,01000 & 0.431 & 0.419 & 0.0055 & 3.859 & 4.715 \\
\hline 2,500 & 0.539 & 0.469 & 0.00061 & $4.63475 \%$ remaining & 5.648 \\
\hline $3,0(x)$ & 0.647 & 0.514 & 0.0067 & 5.381 & 6.548 \\
\hline $3,5() 0$ & 0.754 & 0.555 & 0.0072 & $6.10650 \%$ remaining & 7.422 \\
\hline 4,000 & 0.862 & 0.593 & 0.0077 & 6.812 & 8.275 \\
\hline 4,500 & 0.970 & 0.629 & 0.0082 & $7.50225 \%$ remaining & 9.109 \\
\hline 5,000 & 1.078 & 0.663 & 0.0086 & $8.1790 \%$ remaining & 9.928 \\
\hline 5,500 & 1.185 & 0.696 & 0.0091 & 8.843 & 10.733 \\
\hline 6,0000 & 1.293 & 0.726 & 0.0095 & 9.497 & 11.526 \\
\hline 6,500 & 1.401 & 0.756 & 0.0099 & 10.141 & 12.308 \\
\hline 7,000 & 1.509 & 0.785 & 0.0102 & 10.776 & 13.080 \\
\hline 7,500 & 1.616 & 0.812 & 0.0106 & 11.403 & 13.842 \\
\hline $8,0(0)$ & 1.724 & 0.839 & 0.0109 & 12.023 & 14.597 \\
\hline 8,500 & 1.832 & 0.865 & 0.0113 & 12.635 & 15.343 \\
\hline 9,000 & 1.940 & 0.890 & 0.0116 & 13.241 & 16.1882 \\
\hline $9,5(0)$ & 2.047 & 0.914 & 0.0119 & 13.841 & 16.815 \\
\hline $1(1),(0) 00$ & 2.155 & 0.9 .38 & 0.10122 & 14.436 & 17.541 Half thichnöss renched tw \\
\hline $20,0(0)$ & 4.310 & 1.326 & 0.0173 & 25.479 & 31.133 \\
\hline $30,(00) 0$ & 6.46 .5 & 1.624 & 0.0212 & 35.524 & 43.635 \\
\hline 50,0100 & 10.775 & 2.097 & 0.0273 & 53.997 & 66.897|full ihickness \\
\hline 100,0000 & 21.550 & 2.966 & 0.0387 & 95.304 & 119.859 exceeded \\
\hline
\end{tabular}




\subsubsection{Carbonation}

Carbonation occurs when calcium in concrete reacts with carbon dioxide $\left(\mathrm{CO}_{2}\right)$ to form calcium carbonate according to the following reaction.

$$
\mathrm{Ca}(\mathrm{OH})_{2}+\mathrm{H}_{2} \mathrm{O}+\mathrm{CO}_{2}=>\mathrm{CaCO}_{3}+2\left(\mathrm{H}_{2} \mathrm{O}\right)
$$

The following analytic expression was employed for estimating carbonation rate in the degradation model:

$$
\mathrm{X}=\left(2 \mathrm{D}_{\mathrm{i}} \frac{\mathrm{C}_{\mathrm{gw}}}{\mathrm{C}_{\mathrm{g}}} \mathrm{t}\right)^{1 / 2}
$$

where,

$$
\begin{aligned}
& \mathrm{X}=\text { depth of penetration of carbonation }(\mathrm{cm}) \\
& \dot{D}_{\mathrm{i}}=\text { intrinsic diffusion coefficient of } \mathrm{Ca} \text { in concrete }\left(\mathrm{cm}^{2} / \mathrm{s}\right) \\
& \mathrm{C}_{\mathrm{gw}}=\text { total inorganic carbon in groundwater or soil moisture }\left(\text { mole } / \mathrm{cm}^{3}\right) \\
& \mathrm{C}_{\mathrm{g}}=\mathrm{Ca}(\mathrm{OH})_{2} \text { bulk concentration in concrete solid }\left(\mathrm{mole} / \mathrm{cm}^{3}\right) \text { and } \\
& \mathrm{t}=\text { time }(\mathrm{s})
\end{aligned}
$$

The fourth column of Table 2-5 shows the rate of carbonation for the surface concrete storage modules. This mode of degradation is much slower than the calcium leaching.

\subsubsection{Chloride Penetration}

Chloride from atmospheric chloride and from chlorides scavenged from the air and contained in precipitation was evaluated and found to be the predominant cause of surface concrete degradation (if the concrete was not exposed to freeze/thaw mechanisms as discussed in Section 2.1) for thick walled structures like the concrete storage modules.

The chlorides react with the alkali metal oxides in the concrete causing a lack of strength of the concrete. Loss of alkali metal oxides in concrete essentially convert the concrete to sand and gravel-like components. The degradation formulae for concrete were discussed in Reference 2 as penetration time for initiation time of corrosion of reinforcing bar. The following formula was given in that reference and can be used to predict the rate of chloride penetration. By rearranging the equation one can use it to determine the depth of chloride penetration. The equation given below is the same equation as used in Section 2.2.2.5 to measure onset of reinforcing bar corrosion.

$$
t_{c}=\frac{129 X_{i}^{1.22}}{W C R * l^{0.12}}
$$

where,

$$
\begin{aligned}
& \mathrm{t}_{\mathrm{c}}=\text { time of corrosion }(\mathrm{yr}) \\
& \mathrm{X}_{\mathrm{c}}=\text { depth of penetration of concrete (inches), } \\
& \mathrm{WCR}=\text { water-cement ratio in concrete }(\mathrm{kg} / \mathrm{kg}), \text { and } \\
& \mathrm{Cl}=\text { chloride ion concentration in precipitation }(\mathrm{ppm})
\end{aligned}
$$

The fifth column of Table 2-5 shows the calculated chloride penetration of the concrete. 


\subsubsection{Rebar Corrosion}

Reinforcing steel (commonly called rebar) is used in concrete structures to increase tensile strength of the structure. Corrosion of the rebar is another possible mechanism of vault degradation. Corrosion occurs when iron in the rebar reacts with oxygen to form iron oxides. Corrosion of the rebar lowers the strength of the rebar and disrupts the integrity of the surrounding concrete. As the rebar corrodes, the tensile strength of the structure declines.

The analysis of failure of the surface concrete storage modules were evaluated to see when the reinforcing steel might be lost and what the consequence of loss of this rebar was to the integrity of the modules.

Corrosion of steel reinforcement results in a loss of cross-sectional area of the rebar. Thus, the corrosion of reinforcing steel due to oxygen diffusion occurs in two steps. First, the passivating layer must be broken down before the onset of corrosion. The time to onset of corrosion was approximated by:

where,

$$
t_{c}=\frac{129 \mathrm{Xc}^{122}}{W C R * \mathrm{Cl}^{0.42}}
$$

$$
\begin{aligned}
& t_{c}=\text { time to onset of corrosion }(\mathrm{yr}), \\
& \mathrm{X}_{\mathrm{c}}=\text { thickness of concrete over rebar (inches), } \\
& \mathrm{WCR}=\text { water-cement ratio in concrete }(\mathrm{kg} / \mathrm{kg}), \text { and } \\
& \mathrm{Cl}=\text { chloride ion concentration in groundwater }(\mathrm{ppm}) .
\end{aligned}
$$

The reaction then proceeds, with a loss of reinforcing steel volume approximated by:

$$
\% \text { Re bar Re maining }=100\left(1-\left(\frac{4 * 9.4\left(\frac{\mathrm{cm}^{3}}{\mathrm{~mole}}\right) \mathrm{sDiCs}(\mathrm{t}-\mathrm{tc})}{\pi \mathrm{d}^{2} \Delta \mathrm{X}}\right)\right)
$$

where,

$$
\begin{aligned}
& s=\text { spacing between reinforcement bars }(\mathrm{cm}), \\
& D_{i}=\text { oxygen diffusion coefficient in concrete }\left(\mathrm{cm}^{2} / \mathrm{s}\right) \\
& C_{\mathrm{gw}}=\text { oxygen concentration in groundwater }\left(\mathrm{mole} / \mathrm{cm}^{3}\right) \\
& \mathrm{t}=\text { time }(\mathrm{s}), \\
& \mathrm{d}=\text { diameter of rebar }(\mathrm{cm}) \\
& \Delta \mathrm{X}=\text { depth of rebar below surface }(\mathrm{in}), \text { and } \\
& \mathrm{Cs}=\text { bulk Ca concentration in concrete solid }(\mathrm{mols} / \mathrm{cm}) .
\end{aligned}
$$

The sixth column of Table 2-5 shows that oxidation of the upper course of rebar in the concrete storage modules (CSM) would start in 1,500 years after lost of institutional control and that in 5,000 years all of that upper course of reinforcing rod would have converted to iron oxide and provide no strength to the CSM.

A structural analysis was performed to see what reliance had to be placed on the strength of the upper course of rebar. The analysis indicates that the upper rebar is unnecessary to support the surface loads on the CSM even if all of the degradation products of the concrete were still in place. The total load is easily carried by the lower course of rebar. They were stressed only at 30 percent of yield stress for the steel. 
The analysis concludes that the loss of the upper course of reinforcing rod has no effect on CSM collapse. By way of contrast, this is the predominant failure mode for underground reinforced concrete vaults like, those discussed in Section 2.2.1.

\subsection{National Precipitation}

Mean annual precipitation (Reference 6) for the United States was subdivided by precipitation ranges was used in the analysis. Emphasis was placed on the eastern and westem parts of the United States where storage facilities might exist. Figure 3-1 shows the precipitation regions used. Table 3-1 shows the nuclear sites that are affected in the continued storage analysis. Table 3-2 provides typical rainfall for the various sites within the $<30$ " precipitation range and defines the mean as 10.5 ". Table 3-3 gives other precipitation data for the five regions used in the degradation analysis.

\subsection{Precipitation Chemistry}

Information on precipitation chemistry was required for the analysis to determine the deterioration of the engineered barriers and SNF and HLW. Precipitation chemistry includes $\mathrm{pH}$, sodium, chloride. nitrate, sulfate, ammonium, calcium, magnesium, and potassium ions. There have been significant decreases in the cation concentration over the last 12 years (Reference 7). Due to the changes experienced in precipitation, the precipitation chemistry was developed from 1994-1996 data. These data were available from USGS National Atmospheric Deposition Program/National Trends Network (NADP/NTN) Web Page (Reference 8). Figures 4-1 through 4-8 present the chemical precipitation concentrations for $\mathrm{pH}$, sodium, chloride, nitrate, sulfate, ammonium, calcium, magnesium, and potassium ions, respectively. Table 4-1 was constructed from these figures using the range midpoint.

\subsection{Relative Humidity}

Information on relative humidity was required to predict the corrosion rate of engineered barriers. The relative humidity data for the sites was obtained from "Local Climatological Data" reports for 1996 (Reference 3). These data are compiled by the National Oceanic and Atmospheric Administration and published annually. The report contains both annual data and average for the previous 30 years. The data used in this analysis are the 30-year data. Battelle Pacific Northwest Division developed the corrosion models used in determining degradation of the stainless steel engineered barrier. In Reference 9, they conclude corrosion of stainless steel proceeds at humidities $\geq 85$ percent.

The 30-year climatological data for relative humidity are given for 46 -hour periods/month. Analysis determined the number of 6-hour periods per month when the relative humidity exceeded 85 percent. These are shown in Table 5-1 along with the calculated percent of the year that the relative humidity exceeded 85 percent. These data were combined with the percent of the year that had precipitation days in Reference 10. This information was used to determine stainless steel corrosion. 


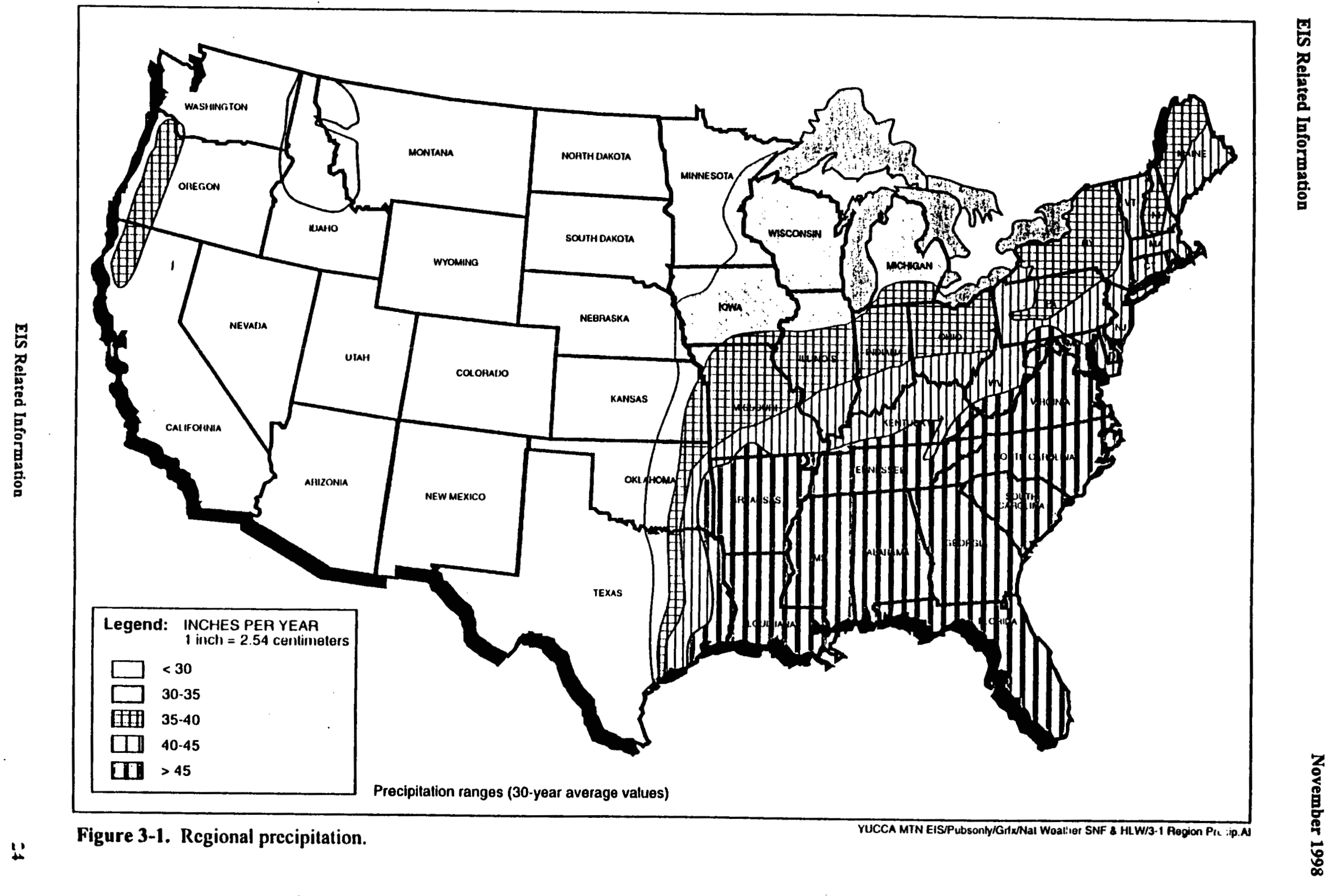


Table 3-1. Nuclear sites in various precipitation regions.

\begin{tabular}{|c|c|c|c|c|}
\hline$<30$ inches/yr & 30-35 inches/yr & $35-40$ inches/yr & $40-45$ inches/yr & $>45$ incheisis \\
\hline $\begin{array}{l}\text { Diablo Canyon } \\
\text { Fort St. Vrain } \\
\text { Palo Verde } \\
\text { Rancho Seco } \\
\text { San Onofre } \\
\text { Washington } \\
\text { Nuclear Power } \\
\text { Hanford } \\
\text { Yucca Mountain } \\
\text { Idaho National } \\
\text { Environmental \& } \\
\text { Engineering } \\
\text { Laboratory }\end{array}$ & $\begin{array}{l}\text { Big Rock Point } \\
\text { Braidwood } \\
\text { Byron } \\
\text { Comanche } \\
\text { Cooper Station } \\
\text { Donald C. Cook } \\
\text { Dresden/Morris } \\
\text { Duane Arnold } \\
\text { Ferni } \\
\text { Fort Calhoun } \\
\text { Kewaunee } \\
\text { Lacrosse } \\
\text { La Salle } \\
\text { Montecello } \\
\text { Palisades } \\
\text { Point Beach } \\
\text { Prairie Island } \\
\text { Quad Cities } \\
\text { Seabrook } \\
\text { Wolf Creek } \\
\text { Zion }\end{array}$ & \begin{tabular}{l} 
Callaway \\
Clinton \\
Davis Besse \\
Humboldt Bay \\
James A. Fitzpatrick \\
Nine Mile Point \\
Perry \\
Trojan \\
Yankee-Rowe \\
West Valley \\
\multicolumn{1}{c}{ Demonstration } \\
Project
\end{tabular} & $\begin{array}{l}\text { Beaver Valley } \\
\text { Haddam Neck } \\
\text { Hope Creek } \\
\text { Indian Point } \\
\text { Limerick } \\
\text { Maine Yankee } \\
\text { Millstone } \\
\text { Oyster Creek } \\
\text { Peach Bottom } \\
\text { Pilgrim } \\
\text { Salem } \\
\text { South Texas } \\
\text { Susquehanna } \\
\text { Three Mile Island } \\
\text { Vermont Yankee }\end{array}$ & $\begin{array}{l}\text { Arkansas Nuclear } \\
\text { Bellefonte (not } \\
\text { started up) } \\
\text { Browns Ferry } \\
\text { Brunswick } \\
\text { Calvert Cliffs } \\
\text { Catawba } \\
\text { Crystal River } \\
\text { Grand Gulf } \\
\text { Hatch } \\
\text { H. B. Robinson } \\
\text { Joseph M. Farley } \\
\text { McGuire } \\
\text { North Anna } \\
\text { Oconee } \\
\text { River Bend } \\
\text { Savannah River Site } \\
\text { Sequoyah } \\
\text { Shearon Harris } \\
\text { St. Lucie } \\
\text { Summer } \\
\text { Surry } \\
\text { Turkey Point } \\
\text { Vogtle } \\
\text { Waterford } \\
\text { Watts Bart }\end{array}$ \\
\hline
\end{tabular}

Table 3-2. Annual precipitation (inches/yr) at sites with less than 30 inches of precipitation.

\begin{tabular}{llc}
\multicolumn{1}{c}{ Site } & \multicolumn{1}{c}{ Location } & $\begin{array}{c}\text { Precipitation } \\
\text { inches per year }\end{array}$ \\
\hline Rancho Seco & Sacramento, CA & 22.4 \\
Diablo Canyon & Santa Maria, CA & 12.4 \\
San Onofre & San Diego, CA & 10.9 \\
Palo Verde & Phoenix, AZ & 7.6 \\
WNP-2 \& 3 & Richland, WA & 8.2 \\
Hanford & Richland, WA & 8.2 \\
Yucca Mountain & Las Vegas, NV & 4.13 \\
INEEL & Idaho Falls, ID & 7.62 \\
Fort St. Vrain & Denver, CO & 16.1 \\
Mean & & 10.5 \\
\hline
\end{tabular}


Table 3-3. Precipitation rates for analysis.

\begin{tabular}{|c|c|c|c|c|c|}
\hline Precipitation regions & $<30$ & $30-35$ & $35-40$ & $40-45$ & $>45$ \\
\hline \multicolumn{6}{|l|}{ Average Yearly Conditions } \\
\hline Total Precipitation, in. & 11 & 32.5 & 37.25 & 42.5 & 50 \\
\hline Days with precipitation & 86 & 120 & 122 & 110 & 107 \\
\hline Dry days & 279 & 236 & 244 & 246 & 249 \\
\hline \multicolumn{6}{|l|}{ Daily Precipitation (in $/ 24$ hours) } \\
\hline Maximum (50 year recurrence) & 1.74 & 5.07 & 5.81 & 6.63 & 7.80 \\
\hline Average & 0.131 & 0.271 & 0.333 & 0.386 & 0.467 \\
\hline \multicolumn{6}{|l|}{ Hourly Precipitation (in/single hour) } \\
\hline Maximum (50 year recurrence) & 0.76 & 2.21 & 2.53 & 2.89 & 3.40 \\
\hline Average & 0.0054 & 0.0113 & 0.0139 & 0.0161 & 0.0195 \\
\hline
\end{tabular}




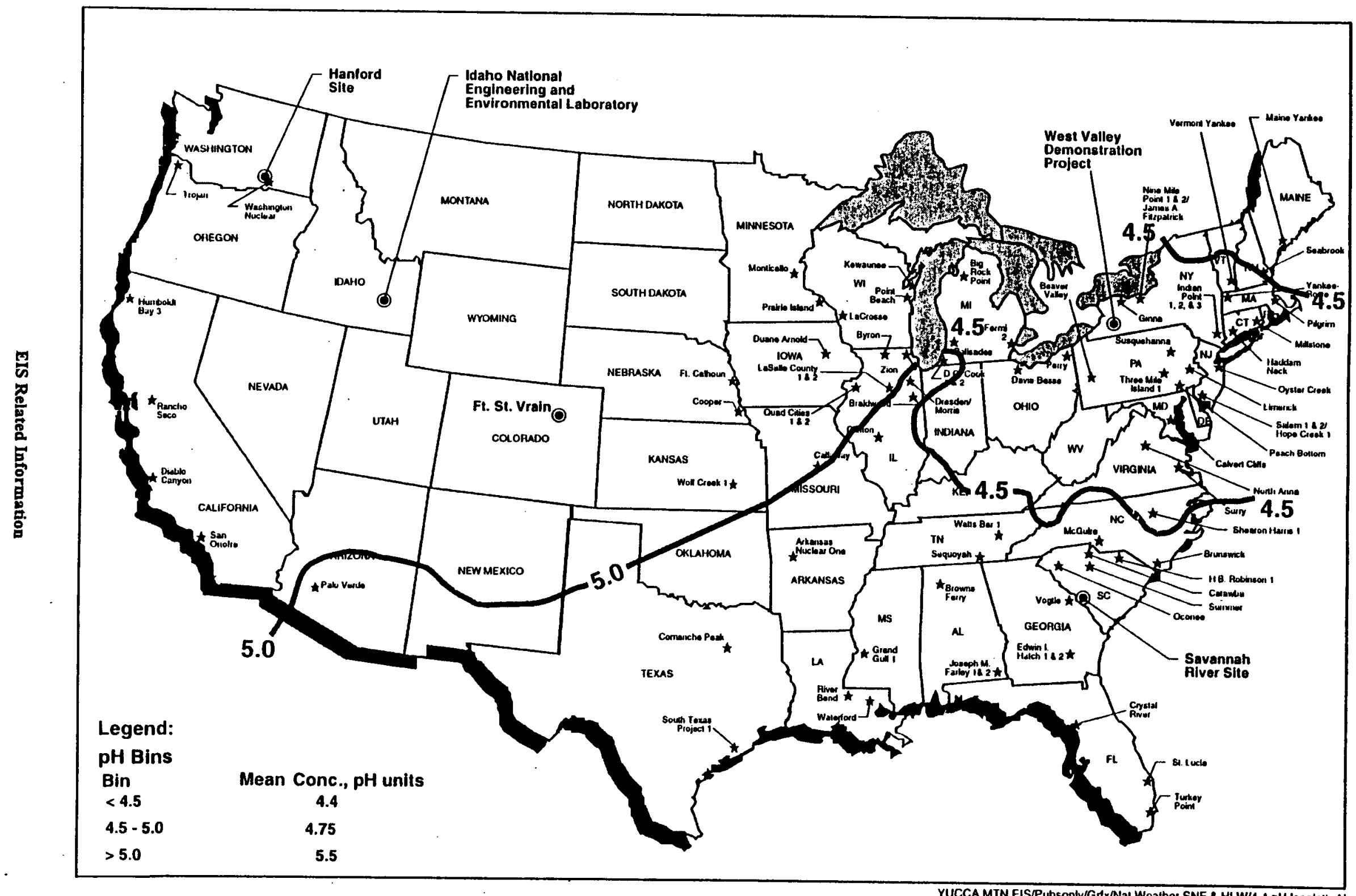

团

Figure 4-1. pH Isopleths.

YUCCA MTN EIS/Pubsonly/Grix/NaI Weather SNF \& HLW/4-1 pH Isopleth AI 


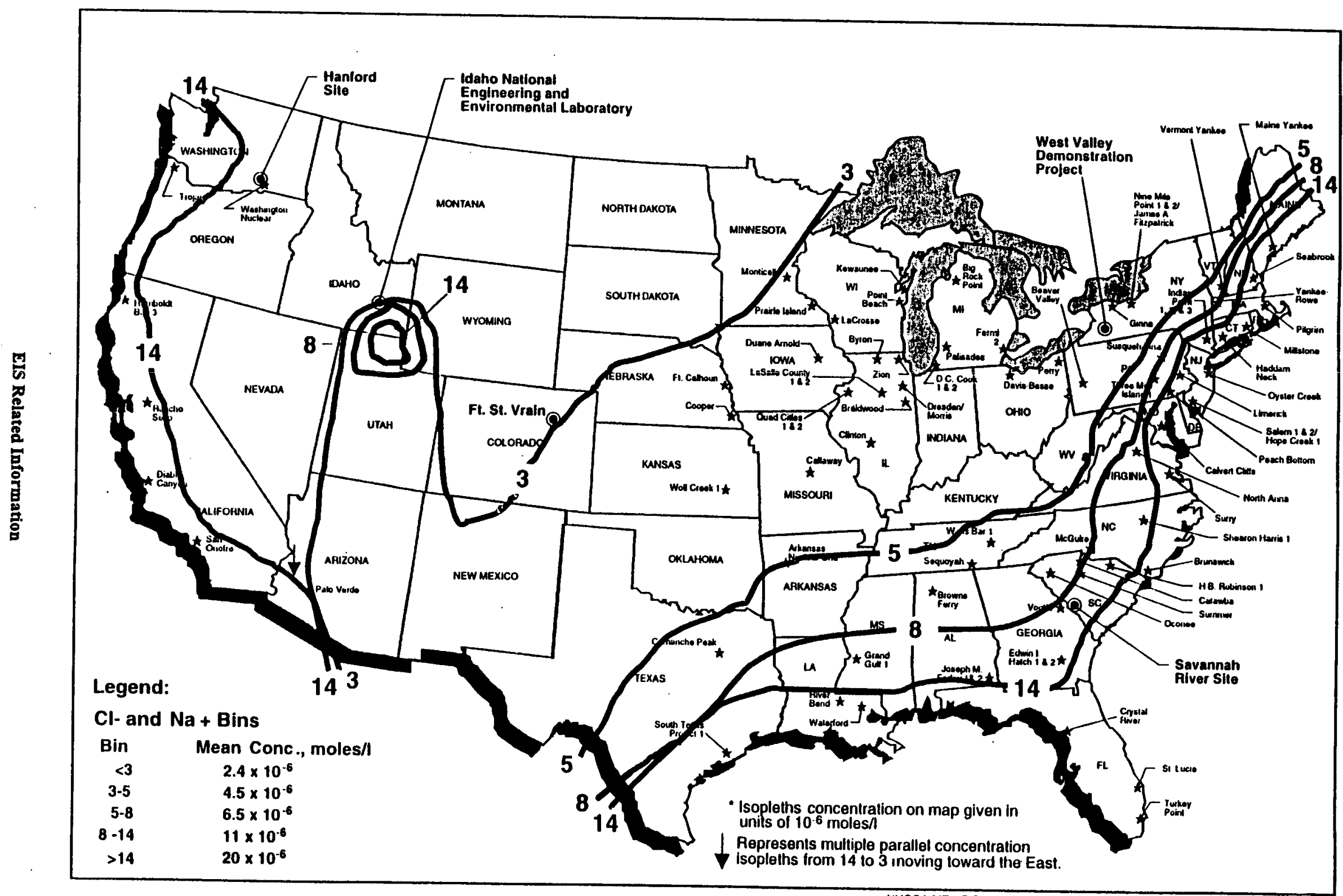

Figure 4-2. Chloride and Sodium Concentration Isopleths*.

YUCCA MTN EIS/Pubsonly/Grix/Nal Wealther SNF \& HLW/4.2 Chlor \& Sodium !so Al 


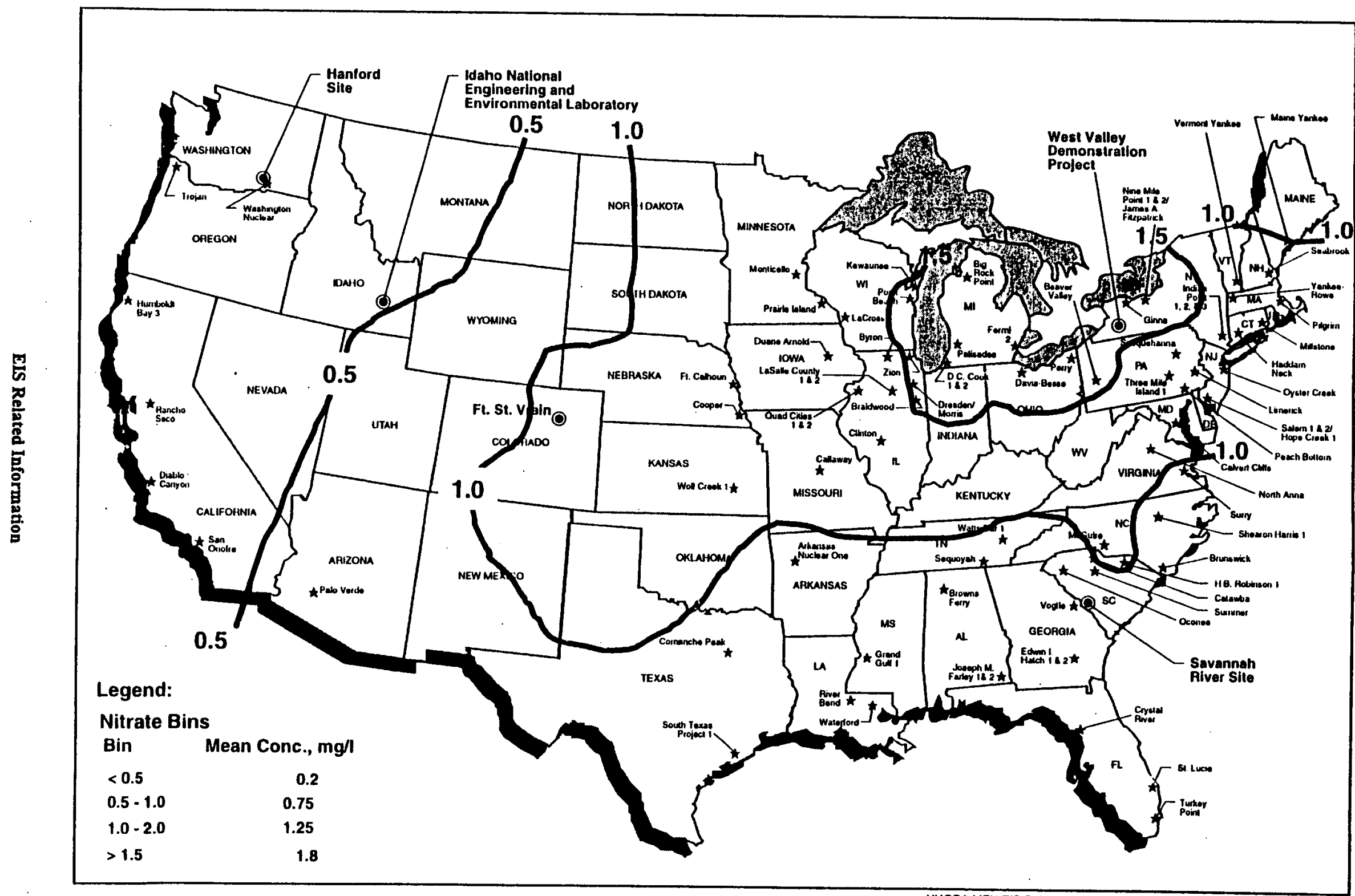

Figure 4-3. Nitrate Ion Concentration Isopleths.

YUCCA MTN EIS/Pubsonly/Grtwat Wogther SNF \& HLW/4-3 Nitrate lon Iso A 


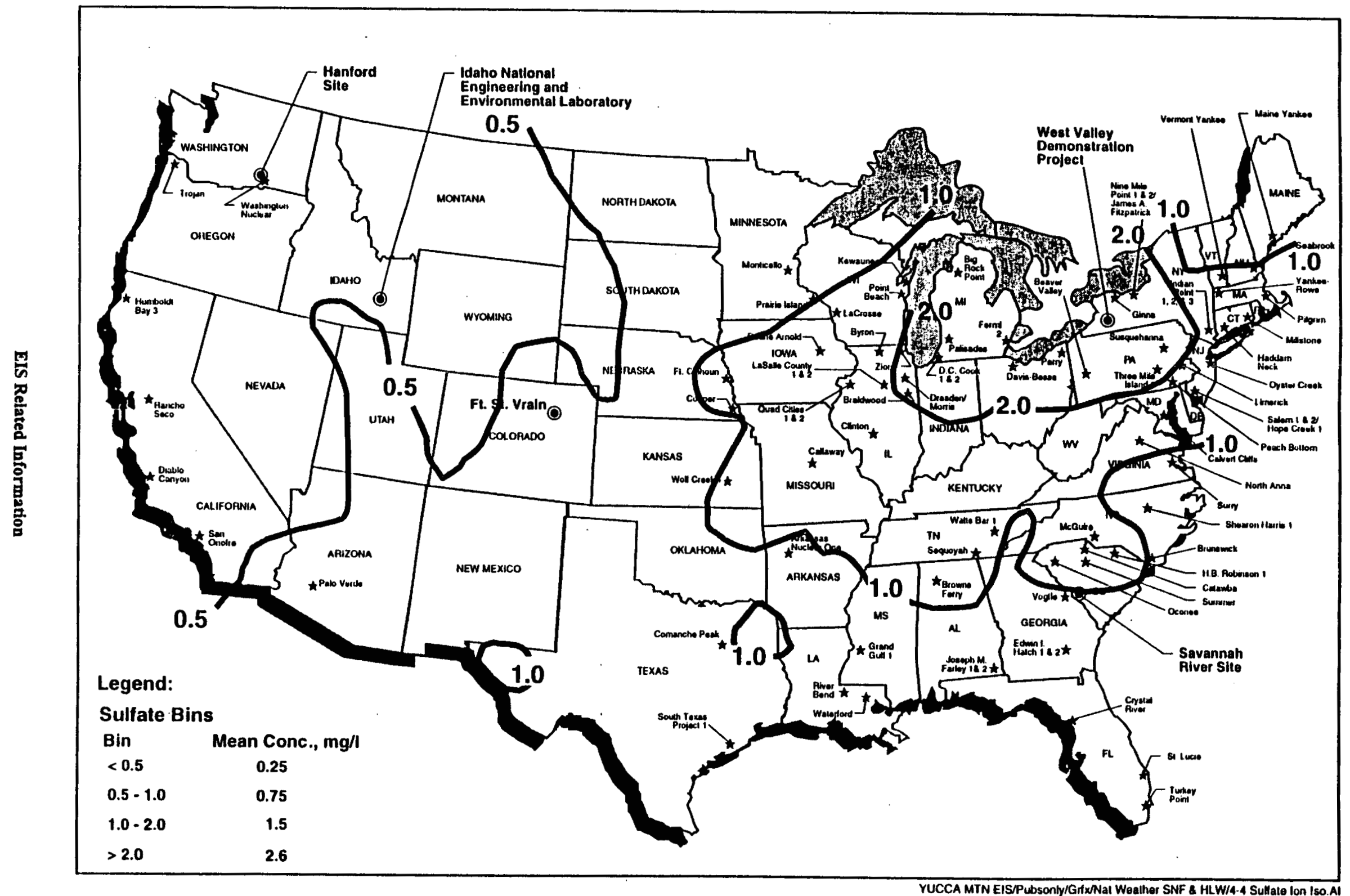

Figure 4-4. Sulfate Ion Concentration Isopleths. 


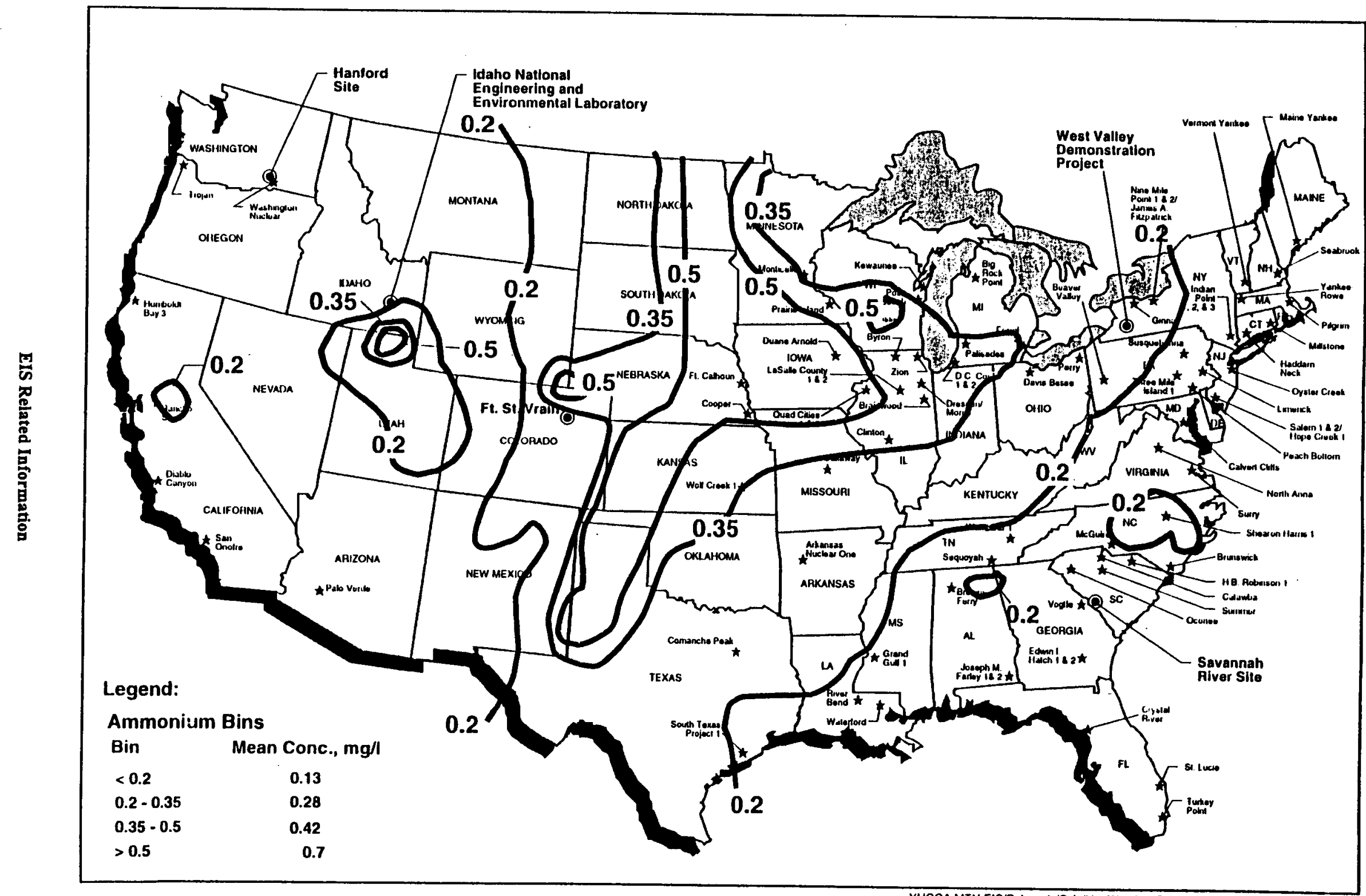




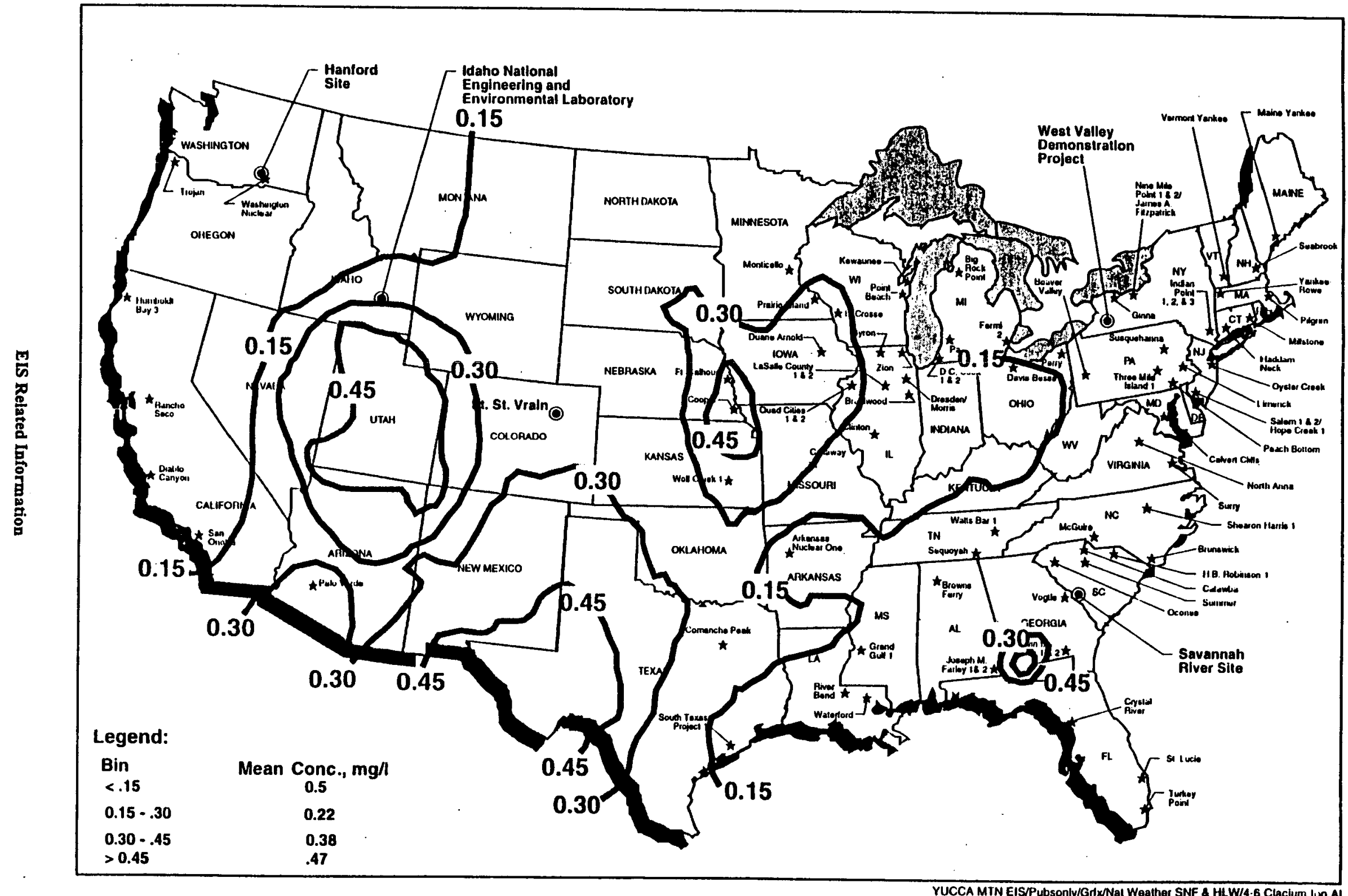

Figure 4-6. Calcium Ion Concentration Isopleths. 


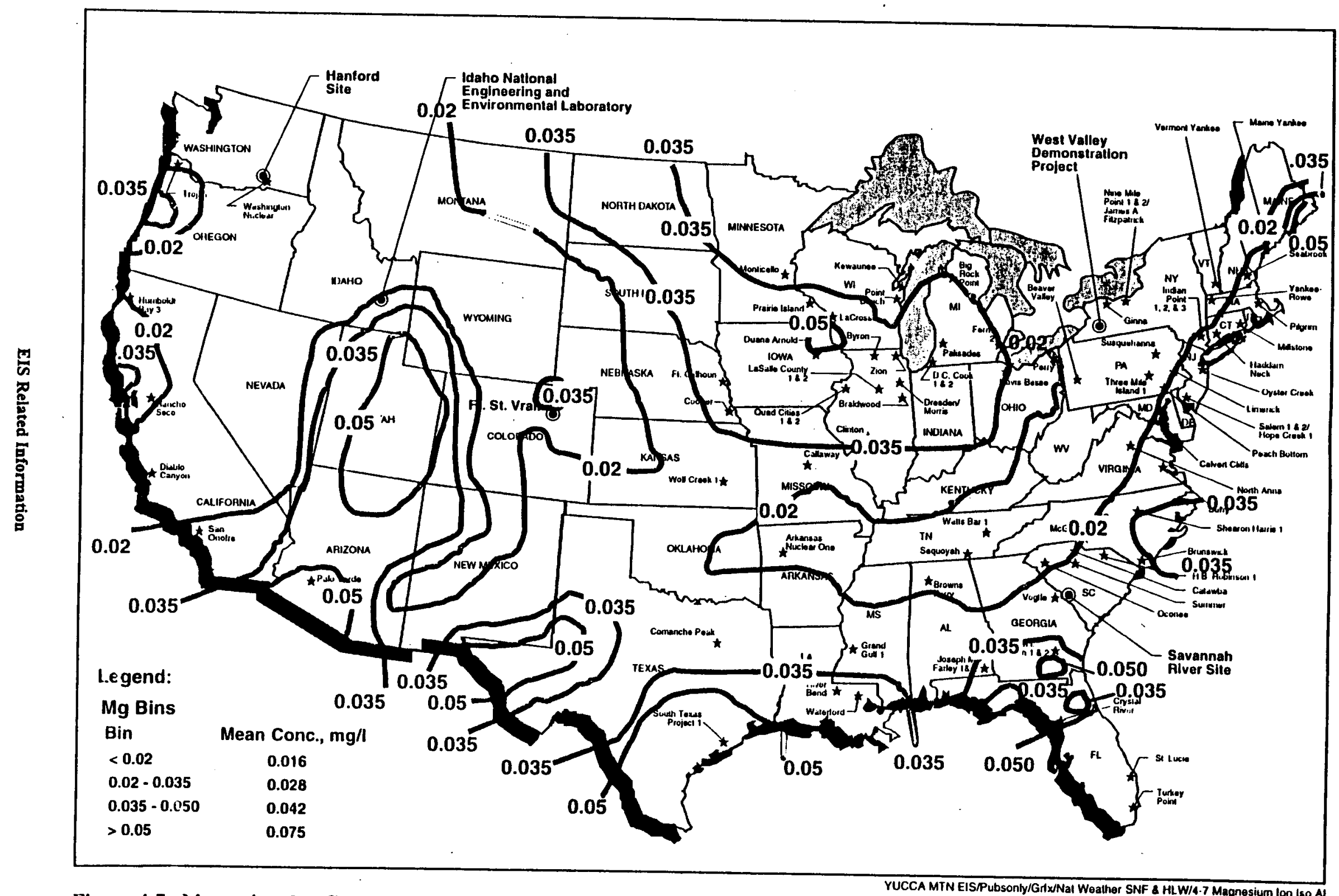




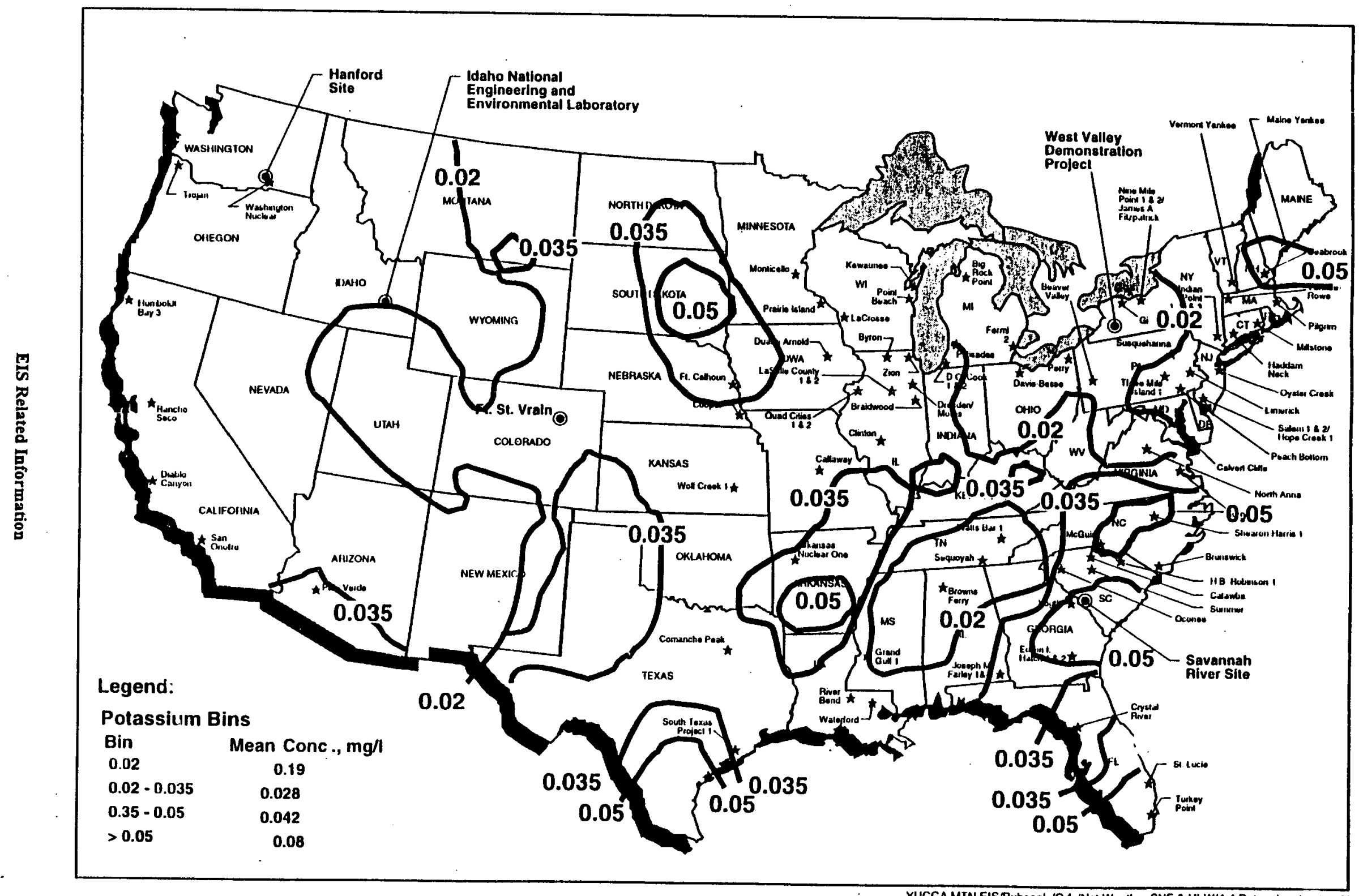

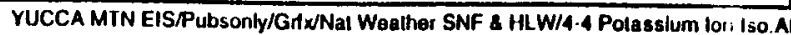


Table 5-1. National temperature and relative humidity data.

\begin{tabular}{|c|c|c|c|c|c|}
\hline \multirow[b]{2}{*}{ Site } & \multirow[b]{2}{*}{$\begin{array}{l}\text { Site location } \\
\text { near-by city }\end{array}$} & \multicolumn{4}{|c|}{ Relative humidity } \\
\hline & & State & $\begin{array}{c}6 \mathrm{hrs} / \text { month } \\
\mathrm{RH}>85 \%\end{array}$ & $\begin{array}{c}\text { Percent of } \\
\text { year }\end{array}$ & $\begin{array}{l}\text { Average } \\
\text { temp for } \\
\text { year, }{ }^{\circ} \mathrm{F}\end{array}$ \\
\hline Browns Ferry & Huntsville & $\overline{A L}$ & 9 & 18.8 & 60.3 \\
\hline Farley & Montgomery & AL & 16 & 33.3 & 64.9 \\
\hline Arkansas Nuclear One & Little Rock & AR & 5 & 10.4 & 60.6 \\
\hline Palo Verde & Phoenix & $\mathbf{A Z}$ & 0 & 0.0 & 72.6 \\
\hline Diablo Canyon & Santa Maria & $\mathrm{CA}$ & 17 & 35.4 & 57.3 \\
\hline Humboldt Bay & Eureka & $\mathrm{CA}$ & 6 & 12.5 & 52.7 \\
\hline Rancho Seco & Sacramento & $\mathrm{CA}$ & 6 & 12.5 & 60.6 \\
\hline San Onofre & San Diego & $\mathrm{CA}$ & 0 & 0.0 & 64.2 \\
\hline Fort St Vrain & Fort Collins & $\mathrm{CO}$ & 3 & 6.3 & 51.5 \\
\hline Haddam Neck & Bridgeport & $C T$ & 0 & 0.0 & 51.7 \\
\hline Millstone & Bridgeport & $C T$ & 0 & 0.0 & 51.7 \\
\hline Salem/Hope Creek & Wilmington & $\mathrm{DE}$ & 0 & 0.0 & 54.2 \\
\hline Crystal River & Tampa & $\mathbf{F L}$ & 17 & 35.4 & 72.3 \\
\hline St. Lucie & West Palm Beach & FL & 4 & 8.3 & 74.7 \\
\hline Turkey Point & Miami & $\mathrm{FL}$ & 5 & 10.4 & 75.9 \\
\hline Hatch & Macon & GA & 11 & 22.9 & 64.8 \\
\hline Vogtle & Augusta & GA & 14 & 29.2 & 63.2 \\
\hline Duane Arnold & Des Moines & IA & 2 & 4.2 & 49.9 \\
\hline Idaho National Engr Laboratory & Idaho Falls & ID & 0 & 0.0 & 50.3 \\
\hline Braidwood & Peoria & II & 4 & 8.3 & 50.7 \\
\hline Byron & Rockford & II & 6 & 12.5 & 47.7 \\
\hline Clinton & Springfield & II & 3 & 6.3 & 50.7 \\
\hline Dresden/Morris & Peoria & II & 4 & 8.3 & 50.7 \\
\hline La Salle County & Peoria & II & 4 & 8.3 & 50.7 \\
\hline Quad Cities & Moline & II & 3 & 6.3 & 49.6 \\
\hline Zion & Chicago & II & 2 & 4.2 & 46.1 \\
\hline Wolf Creek & Wichita & KS & 0 & 0.0 & 56.2 \\
\hline River Bend & Baton Rouge & LA & 16 & 33.3 & 67.7 \\
\hline Waterford & New Orleans & LA & 16 & 33.3 & 68.1 \\
\hline Pilgrim & Boston & MA & 0 & 0.0 & 51.3 \\
\hline Seabrook & Portland & $\mathrm{MA}$ & 6 & 12.5 & 45.4 \\
\hline Calvert Cliffs & Baltimore & $\mathrm{MD}$ & 0 & 0.0 & 58.0 \\
\hline Maine Yankee & Portland & $\mathrm{ME}$ & 6 & 12.5 & 45.4 \\
\hline Big Rock Point & Alpena & MI & 4 & 8.3 & 47.1 \\
\hline Cook & South Bend, Indiana & MI & 2 & 4.2 & 49.5 \\
\hline Enrico Fermi & Detroit & MI & 2 & 4.2 & 48.7 \\
\hline Palisades & Grand Rapids & MI & 3.5 & 7.3 & 49.5 \\
\hline Monticello & Saint Cloud & $\mathrm{MN}$ & 4 & 8.3 & 41.5 \\
\hline Prairie Island & Minneapolis & $\mathrm{MN}$ & 1 & 2.1 & 44.9 \\
\hline Callaway & Columbia & MO & 5.5 & 11.5 & 53.9 \\
\hline Grand Gulf & Vicksburg & MS & 19 & 39.6 & 64.2 \\
\hline Brunswick & Wilmington & $\mathrm{NC}$ & 13 & 27.1 & 63.4 \\
\hline Brunswick & Wilmington & NC & 13 & 27.1 & 63.4 \\
\hline Catawba & Charlotte & NC & 4 & 8.3 & 60.1 \\
\hline Harris & Raleigh & NC & 10 & 20.8 & 59.3 \\
\hline
\end{tabular}


Table 5-1. (Continued).

\begin{tabular}{|c|c|c|c|c|c|}
\hline \multirow[b]{2}{*}{ Site } & \multirow[b]{2}{*}{$\begin{array}{l}\text { Site location } \\
\text { near-by city }\end{array}$} & \multicolumn{4}{|c|}{ Relative humiditv } \\
\hline & & State & $\begin{array}{c}6 \mathrm{hrs} / \mathrm{month} \\
\mathrm{RH}>85 \%\end{array}$ & $\begin{array}{c}\text { Percent of } \\
\text { year }\end{array}$ & $\begin{array}{l}\text { A verage } \\
\text { temp for } \\
\text { year, }{ }^{\circ} \mathrm{F}\end{array}$ \\
\hline McGuire & Charlonte & NC & 4 & 8.3 & 60.1 \\
\hline Cooper & Omaha & NE & 2 & 4.2 & 50.7 \\
\hline Fort Calhoun & Omaha & NE & 2 & 4.2 & 50.7 \\
\hline Oyster Creek & Atlantic City & NJ & 8 & 16.7 & 53.0 \\
\hline Fitzpatrick/Nine Mile Point & Syracuse & NY & 4 & 8.3 & 47.4 \\
\hline Ginna & Rochester & NY & 5 & 10.4 & 47.6 \\
\hline Indian Point & New York & NY & 0 & 0.0 & 54.6 \\
\hline Yankee-Rowe & Albany & NY & 5 & 10.4 & 47.4 \\
\hline West Valley Demo Project & Buffalo & NY & 5 & 10.4 & 54.6 \\
\hline Davis-Besse & Toledo & $\mathrm{OH}$ & 1.5 & 3.1 & 48.5 \\
\hline Perry & Cleveland & $\mathrm{OH}$ & 1 & 2.1 & 49.6 \\
\hline Trojan & Portland & OR & 10 & 20.8 & 53.7 \\
\hline Beaver Valley & Pittsburgh & PA & 2 & 4.2 & 50.3 \\
\hline Limerick & Philadelphia & PA & 1.5 & 3.1 & 54.3 \\
\hline Peach Bottom & Philadelphia & PA & 0 & 0.0 & 54.3 \\
\hline Susquehanna & Wilks Barr & PA & 2 & 4.2 & 49.1 \\
\hline Three Mile Island & Middletown & PA & 0 & 0.0 & 52.9 \\
\hline Oconee & Greenville & SC & 7 & 14.6 & 60.0 \\
\hline Robinson & Columbia & SC & 12 & 25.0 & 60.1 \\
\hline Summer & Spartanburg & SC & 12 & 25.0 & 63.4 \\
\hline Savannah River'Site & Augusta, GA & SC & 14 & 29.2 & 63.2 \\
\hline Sequoyah & Chattanooga & TN & 13 & 27.1 & 59.3 \\
\hline Watts Bar & Chattanooga & $\mathrm{TN}$ & 13 & 27.1 & 59.3 \\
\hline Comanche Peak & Dallas & TX & 2 & 4.2 & 65.4 \\
\hline South Texas & Victoria & TX & 19 & 39.6 & 69.9 \\
\hline North Anna & Richmond & VA & 9 & 18.8 & 57.7 \\
\hline Surry & Norfolk & VA & 1 & 2.1 . & 59.2 \\
\hline Vermont Yankee & Albany, NY & $\mathrm{VT}$ & 5 & 10.4 & 47.4 \\
\hline Washington Nuclear & Richland (Hanford) & WA & 0 & 0.0 & 53.3 \\
\hline Hanford & Richland (Hanford) & WA & 0 & 0.0 & 53.3 \\
\hline Kewaunee & Milwaukee & WI & 2 & 4.2 & 46.1 \\
\hline Lacrosse & La Crosse & WI & 6 & 12.5 & 46.2 \\
\hline Point Beach & Milwaukee & WI & 2 & 4.2 & 46.1 \\
\hline
\end{tabular}




\subsection{Temperature}

\subsection{Annual Average Temperature}

The 30-year average annual ambient air temperature was determined from the climatological data (Reference 3) for each site and is displayed in the last column of Table 5-1.

\subsection{Thermal Analysis of Surface Storage of Commercial SNF}

A thermal analysis was performed on a loaded surface storage unit which contained 24 PWR fuel assemblies irradiated to $40,000 \mathrm{MWD} / \mathrm{MTHW}$ and loaded at $0.66 \mathrm{~kW} / \mathrm{per}$ assembly into a dry storage canister (DSC) (Reference 11). This thermal analysis was needed to guide the degradation analysis and answer a number of questions that were being raised.

A thermal analysis was performed to develop the expected temperatures that the SNF cladding and stainless steel DSC would experience during long-term degradation. The analysis included both the decay heat and the ambient temperature expected during storage. The calculations were based on information from Reference 11 and summarized on Figure 6-1. The results of this analysis can be seen on Figure 6-2a. On that figure the top curve is the calculated SNF cladding temperature and assumes that this is the average summer temperatures based on average temperatures of $80^{\circ} \mathrm{F}$ for Augusta, GA. The other three curves are the expected average summer, average yearly temperature, and the average winter temperatures. These average values are marked on the right margin of the figures.

The two discontinuities (the first at 150 years and the second at 260 years) reflect the loss of natural circulation cooling by vent pluggage at 150 years and roof collapse at 260 years as defined in Reference 2. The curves suggested that the heat from decay of the radionuclides in the SNF has a larger influence on temperatures than do the environmental conditions or the damage.

This initial analysis was useful in the degradation analysis so it was expanded to include ten more locations to span the conditions that are expected for continued storage. Storage locations ranged from the coldest reactor sites which included Monticello near Saint Cloud, MN; Yankee-Rowe near Albany, NY; Ginna near Rochester, NY; and Susquehanna near Scranton, PA. Average winter temperatures at these four sites are 13,24.2, 26.1, and 27.8 degrees $F$, respectively. The hottest sites included Palo Verde near Phoenix, AZ; South Texas near Victoria, TX; and Turkey Point near Miami, FL. Maximum summer temperatures for these sites are 90.6, 83.6, and 82.4 degrees F.. respectively. Two intermediate low temperature sites (Perry near Cleveland, $\mathrm{OH}$; and Braidwood near Peoria. $\mathrm{OH}$ ) were also selected. Rounding out the eleven sites are two intermediate sites (Vogtle near Augusta, GA; and San Onofre near San Diego. CA). Thermal analysis of storage assumed the DSC contained PWR fuel assemblies (Reference 12). Results are shown in Figures 6-2a through 6-2k.

The analysis was repeated assuming the DSC was loaded with 52 BWR assemblies. The results of thermal analysis for these BWR assemblies (Reference 12) is presented in Figure 6-3a through 6-3k. 


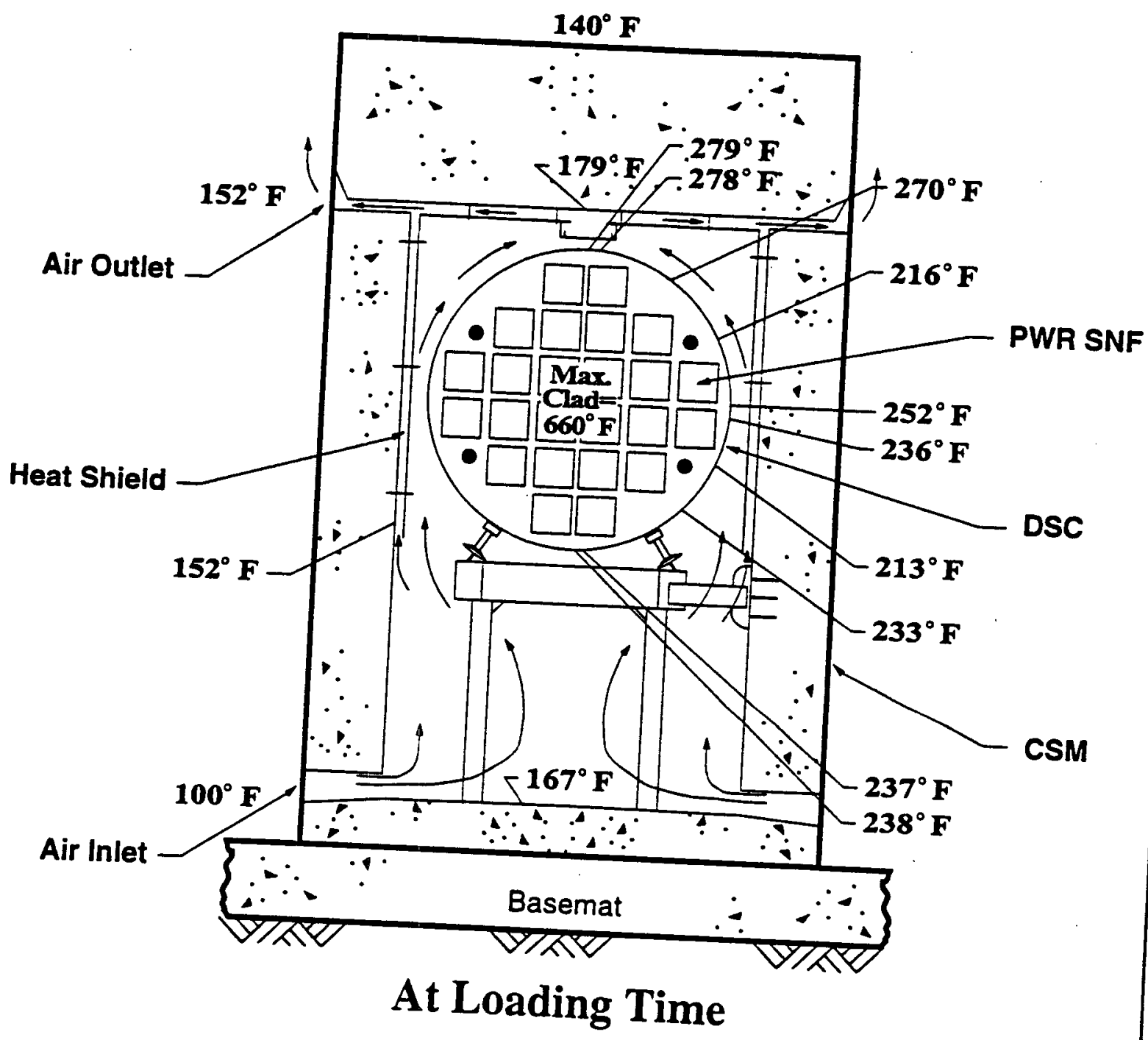

Note: Assumes 24 PWR at 40,000 MWD/MTV loaded at 0.66 with assembly

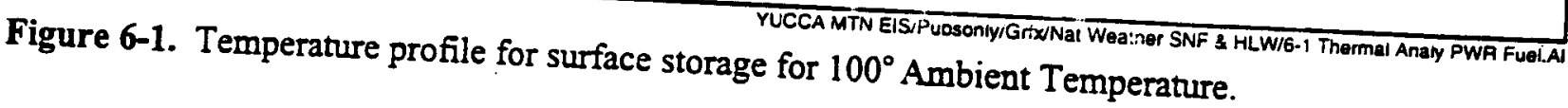




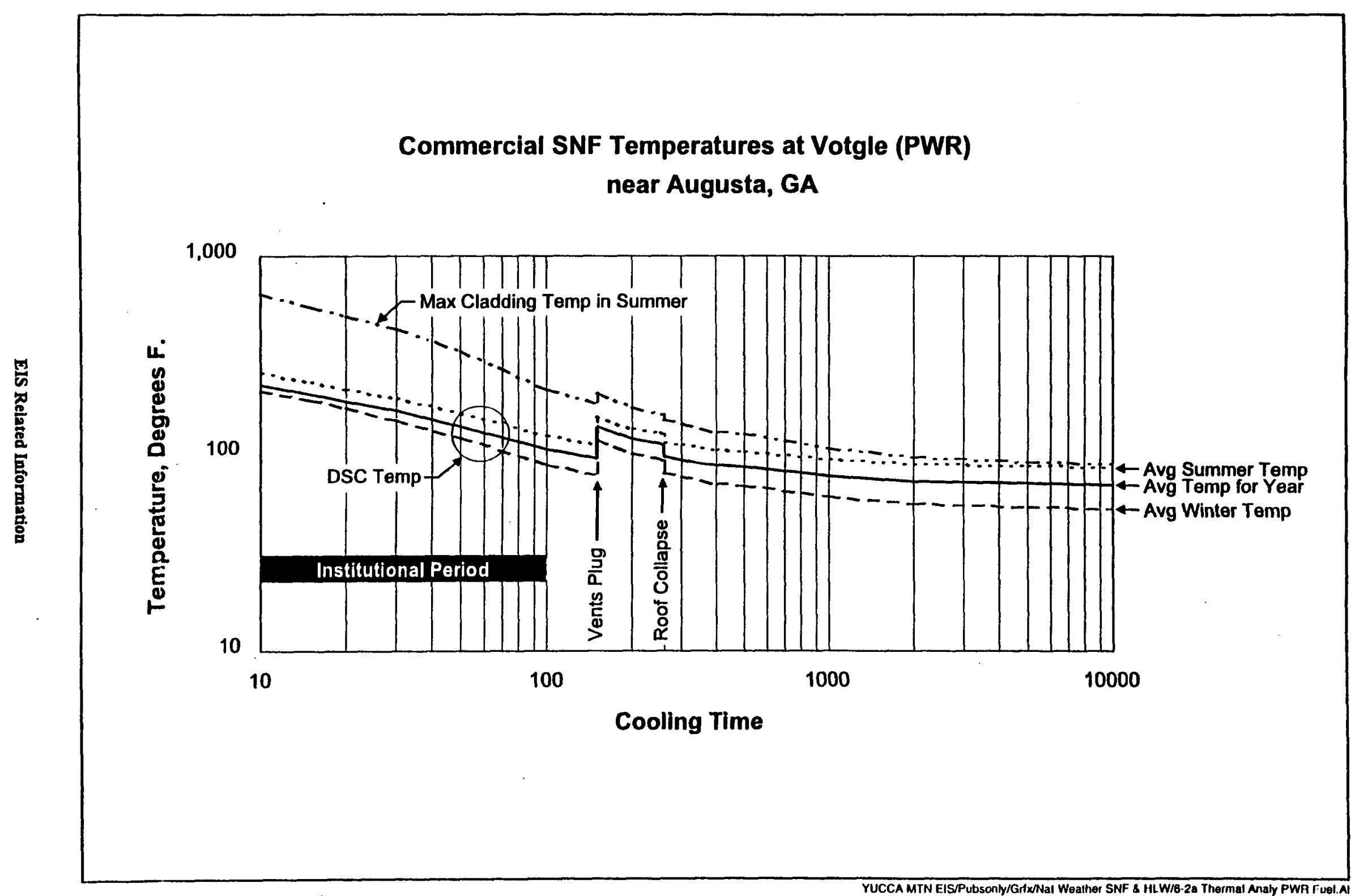



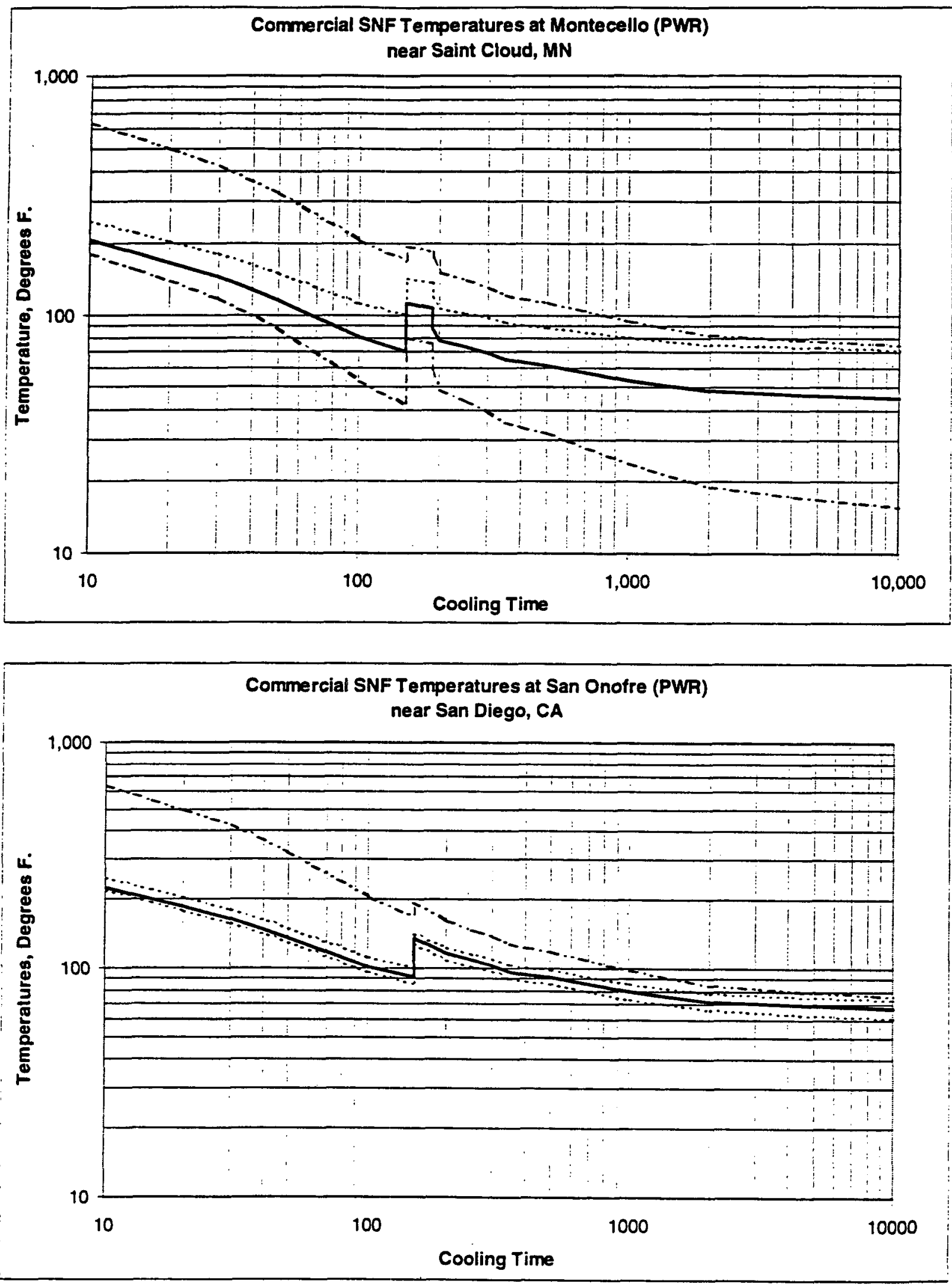

Figures 6-2b and c. Thermal analysis for PWR fuel. 

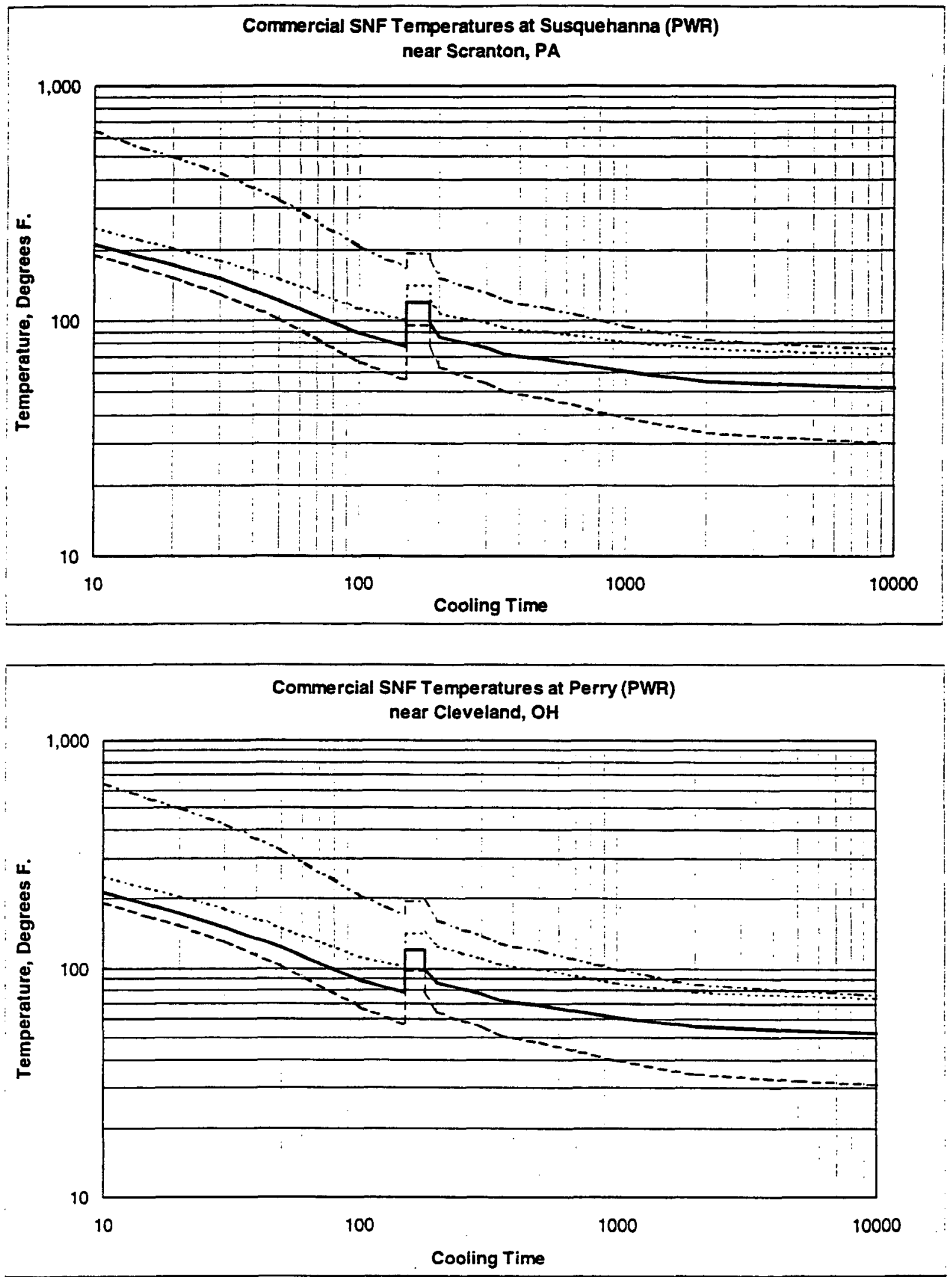

Figures 6-2d and e. Thermal analysis for PWR fuel. 

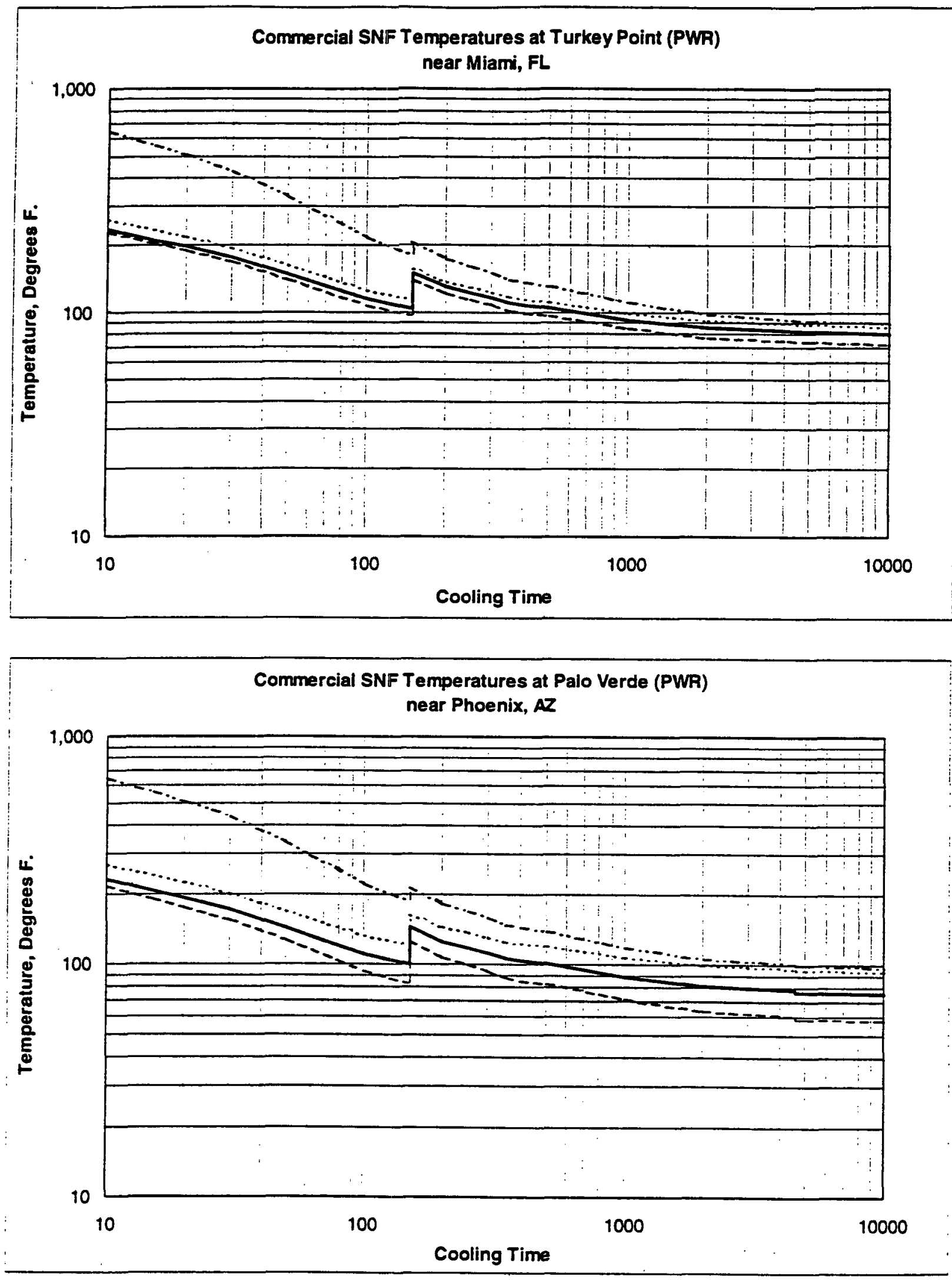

Figures 6-2f and g. Thermal analysis for PWR fuel. 

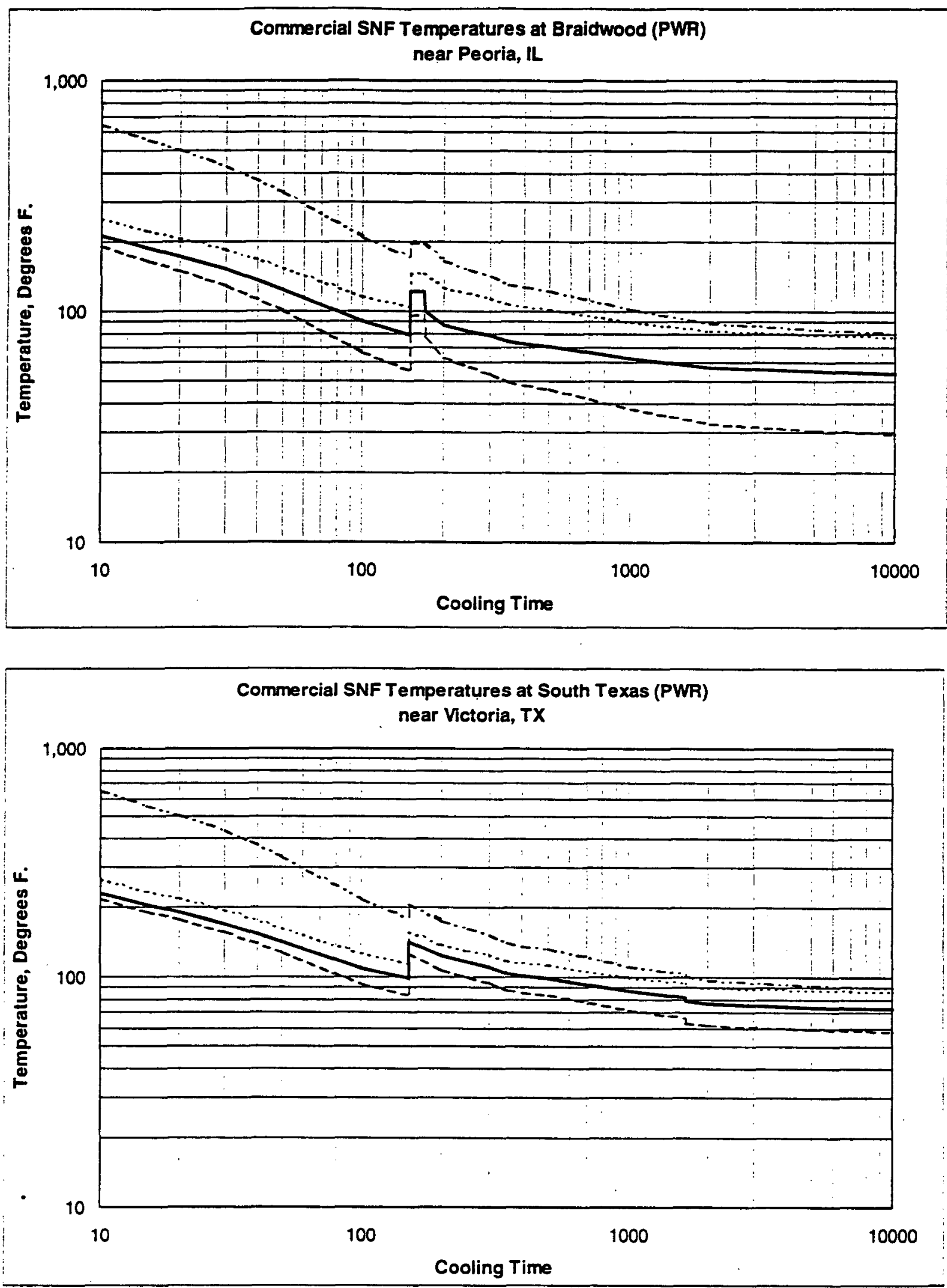

Figures 6-2h and $i$. Thermal analysis for PWR fuel. 

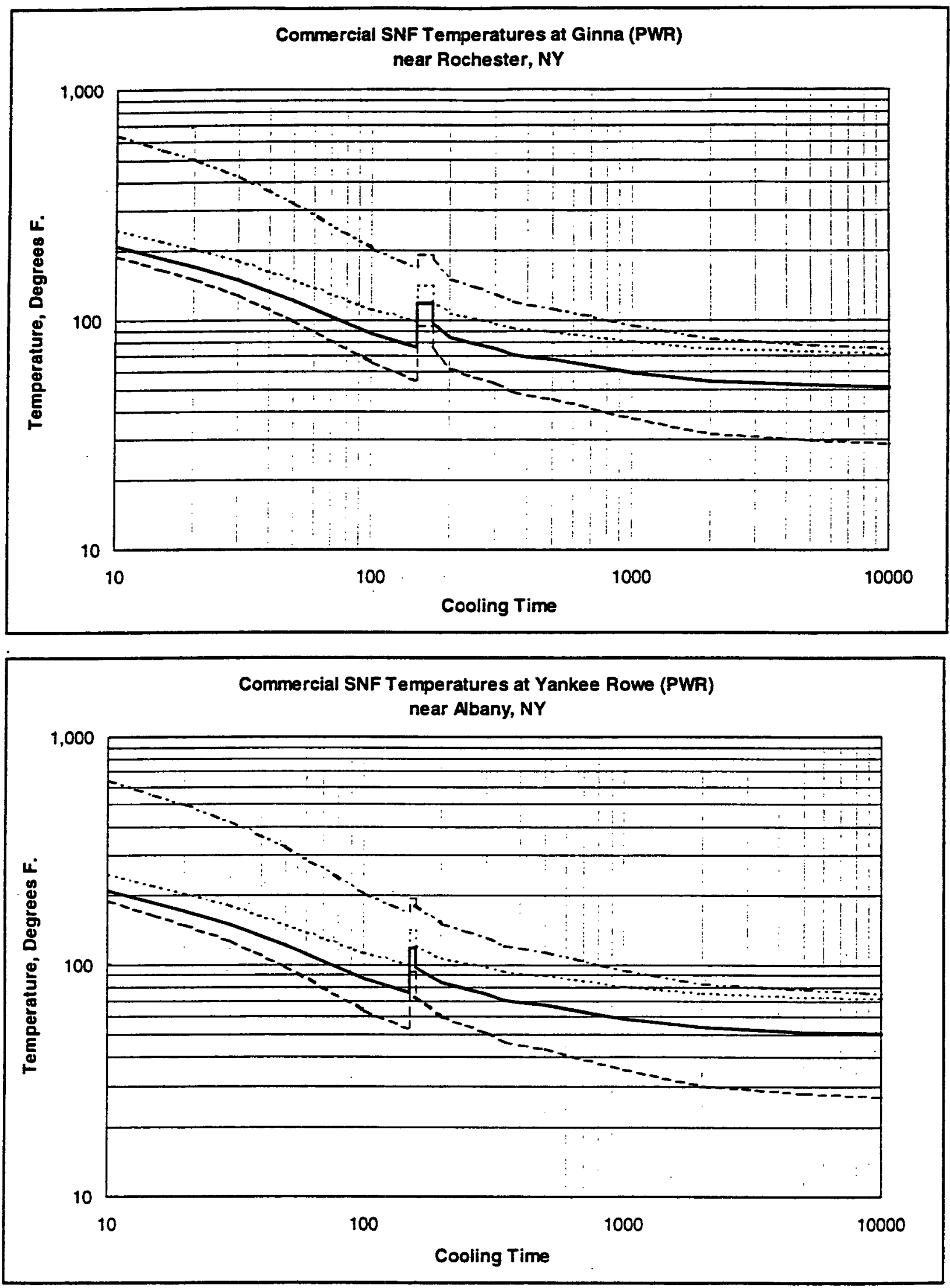

Figures 6-2j and $k$. Thermal analysis for PWR fue! 

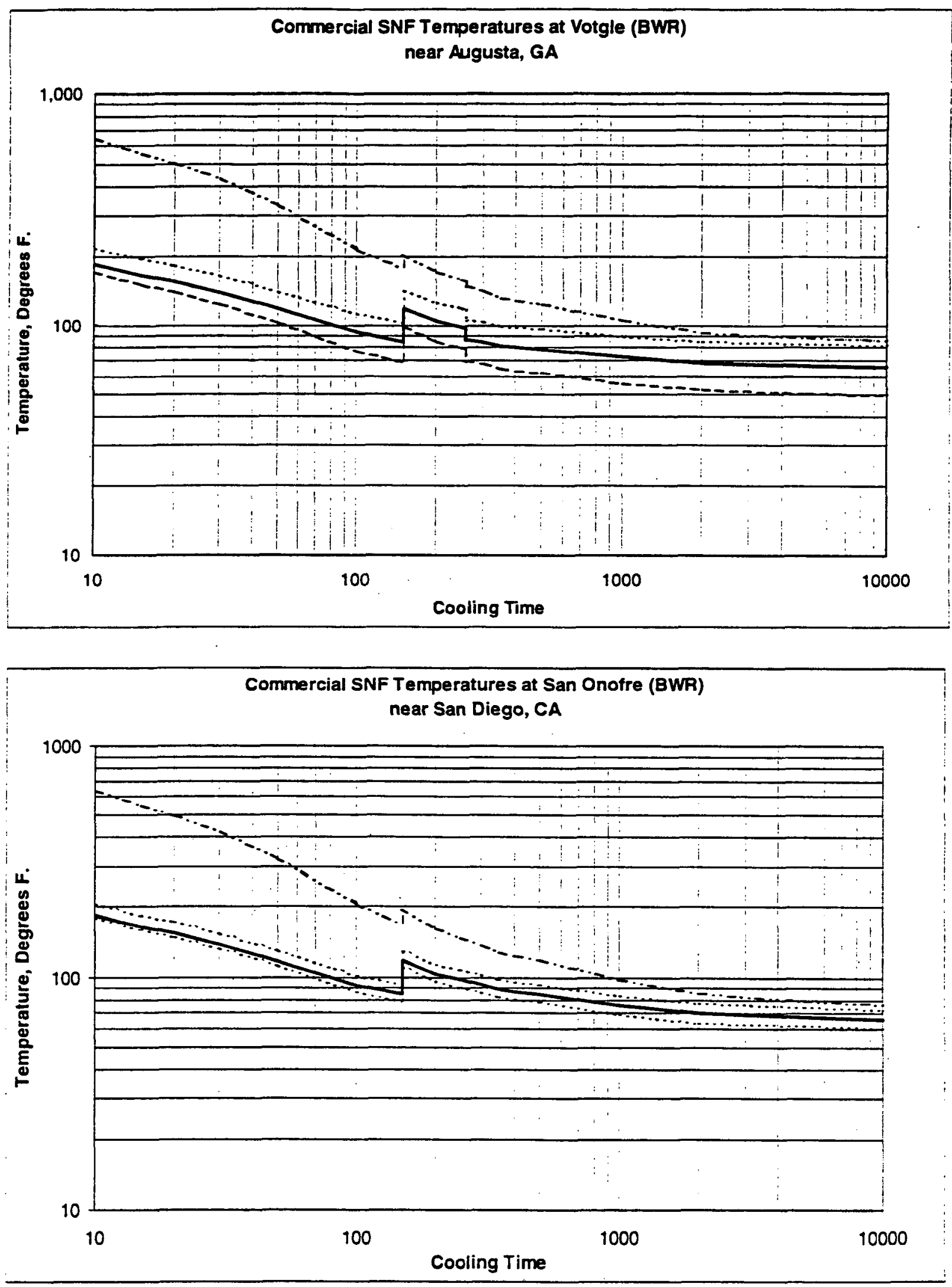

Figures 6-3a and b. Thermal analysis for BWR fuel. 

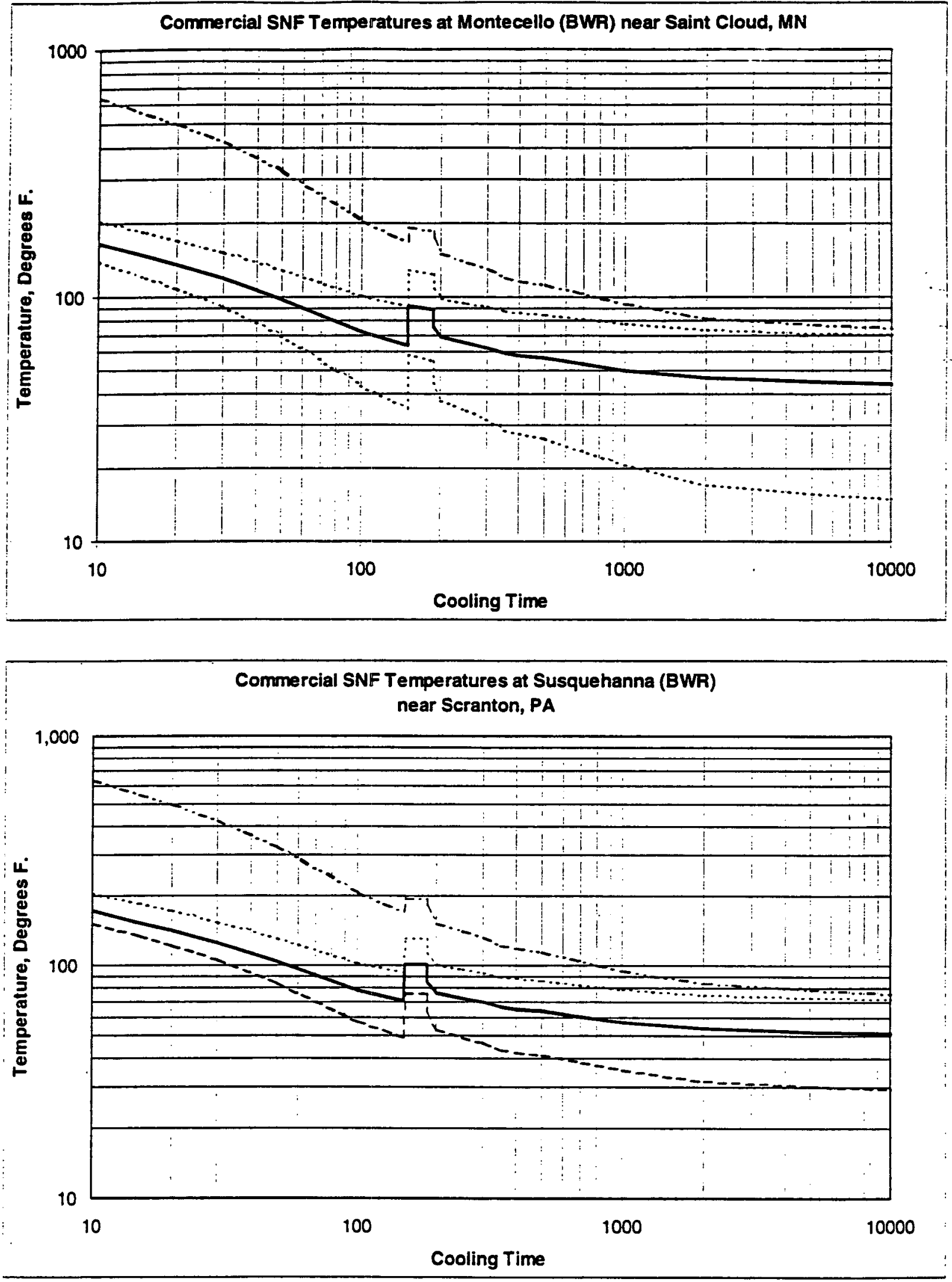

Figures 6-3c and d. Thermal analysis for BWR fuel. 

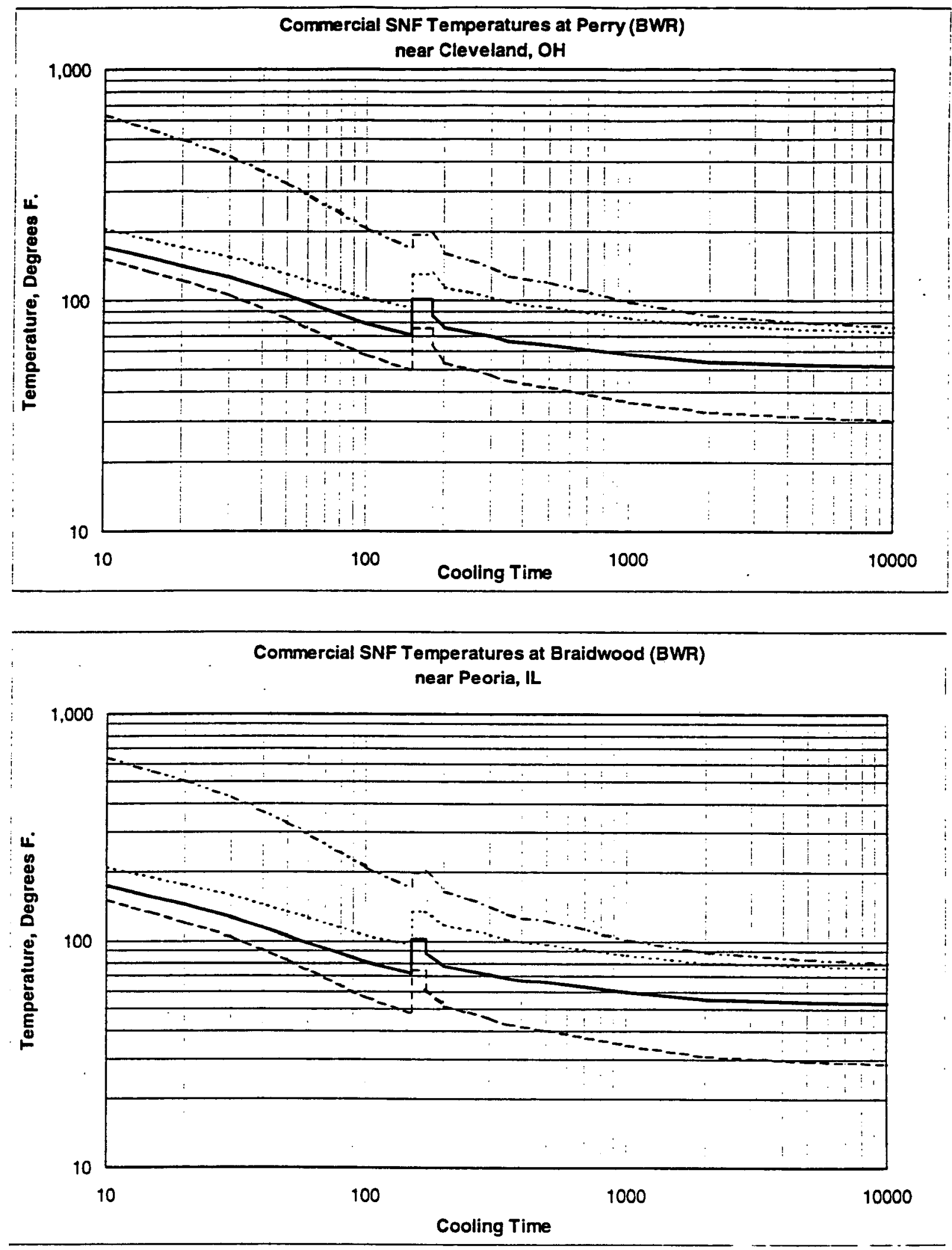

Figures 6-3e and $f$. Thermal analysis for BWR fuel. 

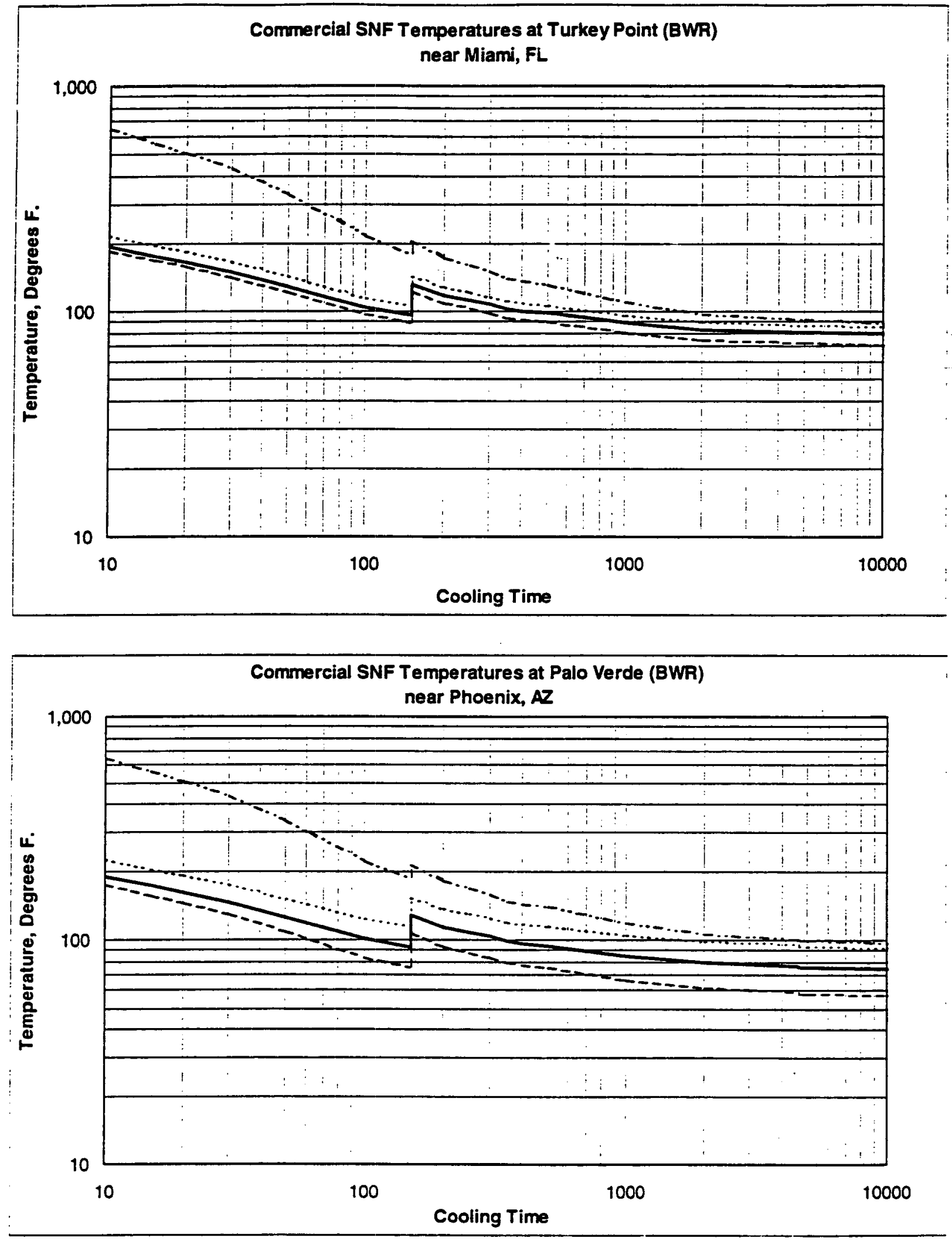

Figures 6-3g and $\mathrm{h}$. Thermal analysis for BWR fuel. 

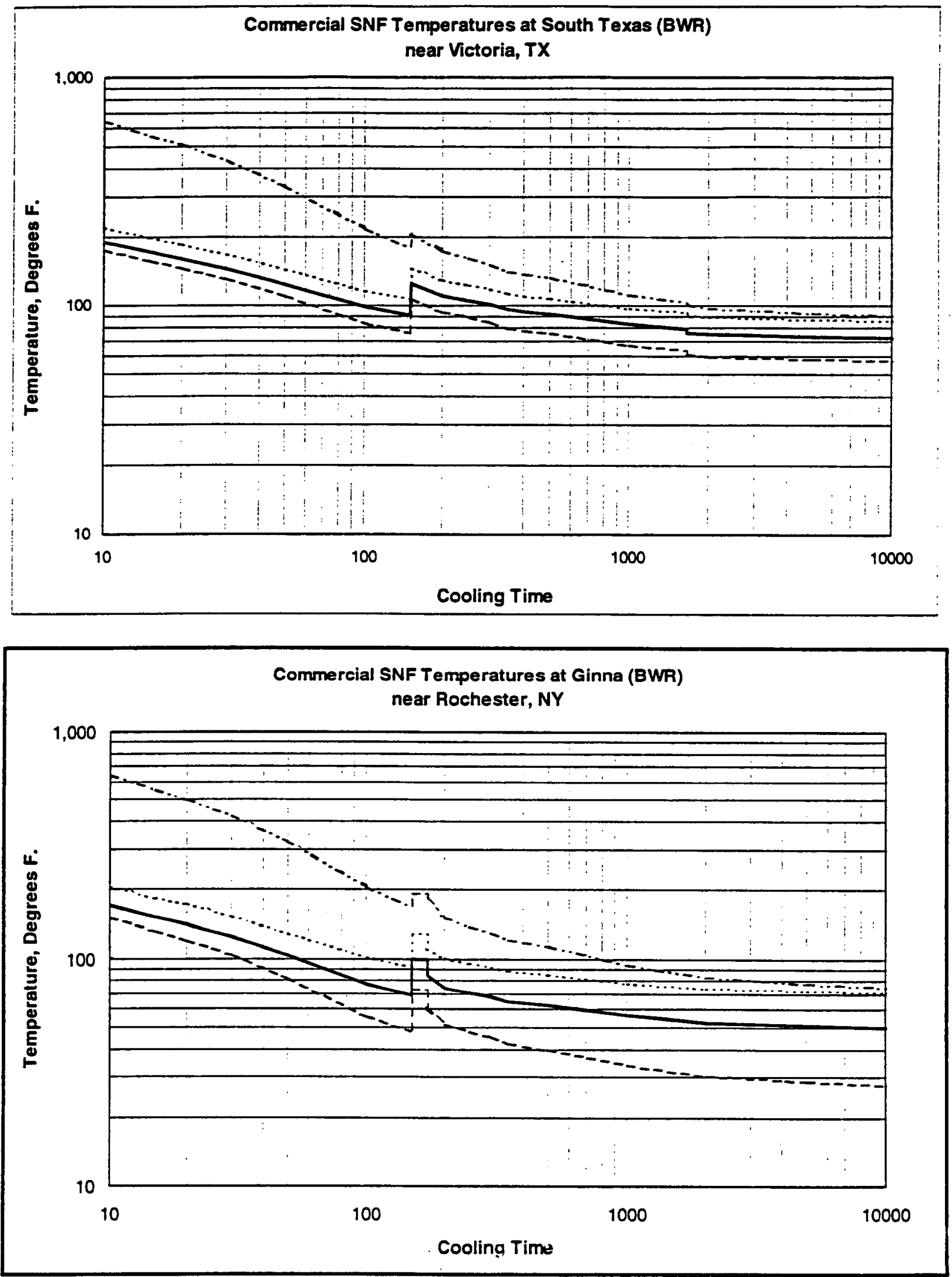

Figures 6-3i and $\mathrm{j}$. Tharmal analysis for BWR fuel. 


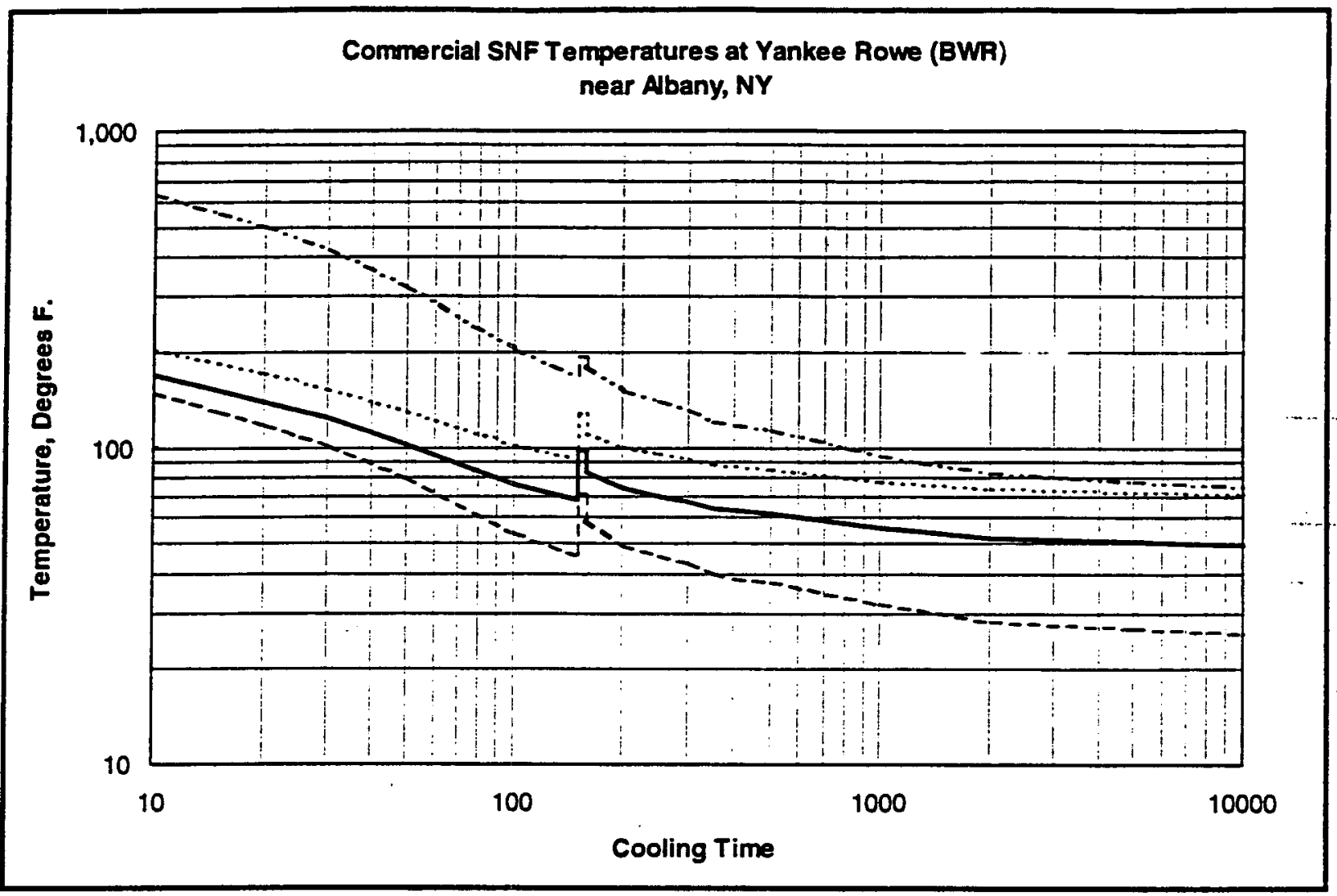

Figure 6-3k. Thermal analysis for BWR fuel. 


\section{References}

Reference 1. "Continued Storage Analysis Report," Revision OI, November 5, 1998.

Reference 2. "Long term Degradation of Concrete Presently Used for Storage of Spent Nuclear Fuel and High-Level Waste", by W. L. Poe, Tetra Tech NUS, Inc., Aiken, SC, October 1998.

Reference 3. NOAA (National Oceanic and Atmospheric Administration), 1996, Local Climatological Data Annual Summary for (city and state), National Climatic Data Center, Asheville, NC.

Reference 4. "Integrated Approach to Modeling Long-Term Durability of Concrete Engineered Barriers in LLRW Disposal Facility," Lee, J.H. et al.

Reference 5. Personal communication from Clay Lawson (DHEC), November 10, 1997.

Reference 6. “Data Book for Civil Engineers-Designs," Third Edition, Seelye, E. E., 1968.

Reference 7. "Trends in Precipitation Chemistry in the United States, 1983-94: An Analysis of the Effects in 1995 of Phase I of the Clean Air Act Amendment of 1990, Title IV," by J. A. Lynch, V. C. Bowersox, and J. W. Grimm, Report 96-0346, USGS for National and Precipitation Program, 1996.

Reference 8. NADP/NTN Web Page addresses Used:

http://nadp.sws.uiuc.edu/isopeths/mapsyear/element or compound.GIF

For Chloride use CL Sulfate use $\mathrm{SO} 4$

Potassium use $\mathrm{K}$

Magnesium use MG

Ammonia use $\mathrm{NH} 4$

Nitrate use NO3

Calcium use $\mathrm{CA}$

$\mathrm{PH}$ use $\mathrm{LABH}$

Reference 9. "Analytical Approach for Estimating Releases of Spent Nuclear Fuel and High-Level Waste for the Yucca Mountain Environmental Impact Statement No-Action Alternative," Battelle Pacific Northwest Division, Richland, Washington.

Reference 10. "Regional Binning for Continued Storage of Spent Nuclear Fuel and High-Level Waste,"

Reference 11. Safety Evaluation Report for "Topical Report for the NUTECH Horizontal Modular Storage System for Irradiated Nuclear Fuel, NUHOMS $®$-24P," (NUH-002), Revision I, April 21 , 1989, Roberts. J. P., Nuclear Regulatory Commission.

Reference 12. Yucca .Mountain EIS, Appendix A. Rev. OA, May 4, 1998. 